\title{
Characteristics and Source Apportionment of VOCs in a City with Complex Pollution in China
}

\author{
Yu Wang ${ }^{1,2}$, Guang Yang ${ }^{1,2}$, Litao Wang ${ }^{1,2 *}$, Le Zhao ${ }^{1,2}$, Shangping $\mathrm{Ji}^{1,2}$, Mengyao Qi ${ }^{1,2}$, \\ XiaoHan Lu',2, Zhentong Liu ${ }^{1,2}$, Jingyao Tan ${ }^{1,2}$, Yingying Liu ${ }^{1,2}$, Qing Wang ${ }^{1,2}$, Ruiguang Xu ${ }^{1,2,3}$ \\ ${ }^{1}$ College of Energy and Environmental Engineering, Hebei University of Engineering, Handan, Hebei 056038, China \\ ${ }^{2}$ Hebei Key Laboratory of Air Pollution Cause and Impact (preparatory), Handan, Hebei 056038, China \\ ${ }^{3}$ Istitute of Earth Environment, Chinese Academy of Sciences, Xi'an 710061, China
}

\begin{abstract}
Volatile organic compounds (VOCs) are important precursors in the formation of ozone $\left(\mathrm{O}_{3}\right)$ and secondary organic aerosol (SOA). Hence, using an online monitor, we measured the concentrations of 56 VOC species in Handan, one of the most polluted cities in China, from Sep. 2017 till Aug. 2018. We also characterized the VOC pollution by measuring the $\mathrm{O}_{3}$ and $\mathrm{NO}_{x}$ and determining the chemical reactivity of the VOCs at different levels of $\mathrm{O}_{3}$ pollution, analyzing the regional $\mathrm{O}_{3}$ formation mechanisms, and apportioning the VOC sources. The daily VOC concentrations displayed a wide range, from 37.7 to $288.9 \mu \mathrm{g} \mathrm{m}^{-3}$, with an average of $112.0 \pm 45.5 \mu \mathrm{g} \mathrm{m}^{-3}$, during the observation period, and the contribution of alkenes and other aromatics to the $\mathrm{O}_{3}$ formation potential (OFP) of the VOCs was higher on medium pollution days than clean days. Furthermore, the majority of the $\mathrm{O}_{3}$ during spring and winter was formed in VOC-sensitive regimes, whereas the high diurnal concentrations during summer and autumn were produced in $\mathrm{NO}_{x}$-sensitive regimes. Based on the $i$-butane $/ n$-butane and $i$-propane/n-propane ratios, the main sources of butane and propane were vehicular exhaust and liquid gasoline, respectively. Source apportionment by principal component analysis (PCA) revealed that the VOCs in Handan originated from vehicular emission, industrial production, solvent use, gasoline evaporation, and combustion.
\end{abstract}

Keywords: Volatile organic compounds; Chemical reactivity; Ozone formation; Source apportionment; Handan city.

\section{INTRODUCTION}

VOCs are ubiquitous in the atmosphere. With the rapid economic growth, increasing energy consumption and vehicle population, VOCs and $\mathrm{O}_{3}$ pollution gradually appears in Chinese cities (Wei et al., 2018). VOCs are important precursors for initiating the formation of ground-level $\mathrm{O}_{3}, \mathrm{SOA}$ and photochemical smog in atmospheric chemistry (Wei et al., 2016; Wang et al., 2017). The photochemical reaction mechanism of $\mathrm{O}_{3}$ and its precursors (i.e., VOCs and $\mathrm{NO}_{x}$ ) has been widely studied at home and abroad (Kasparoglu et al., 2018; Tan et al., 2018). In particular, regional $\mathrm{O}_{3}$ pollution has become a major environmental problem in megacities of China, such as Beijing, Zhengzhou, and Shanghai (Gao et al., 2017; Li et al., 2017; Wei et al., 2018). Some VOCs such as benzene and 1,3-butadiene are human toxic which have been listed as carcinogens by the U.S. EPA (U.S. EPA, 1990). VOC pollution characteristics, chemical components and source apportionment are one of the research hotspots in China in

\footnotetext{
* Corresponding author.

E-mail address: wanglitao@hebeu.edu.cn
}

recent years. Many VOCs studies are focused on Yangtze River Delta (YRD), Pearl River Delta (PRD) and Beijing-TianjinHebei (BTH) region (Li et al., 2013; Zhang et al., 2013; Xu et al., 2017). Zheng et al. (2013) found that paint manufacturing, wood furniture coating, and metal surface coating are main sources of aromatics and oxygenated VOCs in PRD (Zheng et al., 2013). Wei et al. (2018) simulated the impact of VOCs emission of petrochemical industrial zone on the summertime $\mathrm{O}_{3}$ in Beijing using the WRF-Chem model system (Wei et al., 2018). Gong et al. (2017) found VOCs concentrations were higher in the underground subway compared to the above-ground track, and the life carcinogen risk of commuters in subway was above the acceptable level in Shanghai.

Handan locates in the southern margin of Hebei and is the intersectional city of Shanxi, Shandong, Henan and Hebei Province. Its major industries include coal production, iron and steel industry, cement, and chemical industry, which are all dense energy-consumption and emission industries (Meng et al., 2016; Zhao Le and Tan, 2019). Handan was listed in the ten top polluted cities in China since 2013 (Ministry of Ecology and Environment of the People's Republic of China; http://www.mee.gov.cn/hjzl/). $\mathrm{PM}_{2.5}$ is the major air pollutant in Handan, but the $\mathrm{O}_{3}$ concentrations showed a rapid increase in recent years. Since 2016, $\mathrm{O}_{3}$ has replaced $\mathrm{PM}_{2.5}$ 
to be the major primary pollutant in summer in Handan. On November 7, 2018, Handan government promulgated the Volatile Organic Compound Prevention and Control Action Plan and set a target of 18 VOCs species reduction from 2018 till 2020 (The People's Government of Heibei Province; http://info.hebei.gov.cn//eportal/ui?pageId=1981538\&articleK $e y=14459367 \mathrm{aa} \&$ columnId $=6910479)$. The limit of VOCs emission will be reduced to 250,000 tons in 2020, > 23\% lower than the guideline established in 2015. Many previous studies on air pollution in Handan focused on PM pollution (Wei et al., 2015; Ma et al., 2016; Zhang et al., 2018; Zhe et al., 2019); however, very few studies focused on the increasing VOCs pollution. The objective of this paper to understand the pollution characteristics, chemical reactivity of VOCs in different level of $\mathrm{O}_{3}$ pollution, formation process of $\mathrm{O}_{3}$ pollution episode, and source apportionment of VOCs in Handan, to provide policy-making support for future VOCs and $\mathrm{O}_{3}$ pollution control.

\section{METHODS}

\section{Sampling Site and Data Collection}

VOCs concentrations were online monitored from Sep. 2017 to Aug. 2018 in Handan $\left(114.5-143.9^{\circ} \mathrm{E}, 36.6-40.8^{\circ} \mathrm{N}\right)$. The observation site located on the roof of the Energy and Environment Laboratory, a four-floor building in the campus of Hebei University of Engineering (HEBEU) $\left(36.57^{\circ} \mathrm{N}\right.$, $114.51^{\circ} \mathrm{E}$ ), and it is about $10 \mathrm{~m}$ above the ground. This site, as show in Fig. 1, is located in the southern urban part of Handan, a typical mixed educational and residential area. There are no obvious emission sources and tall obstacles within $2 \mathrm{~km}$ around the site. $\mathrm{NO}_{x}$ and meteorological parameters were measured at the same site. $\mathrm{NO}_{x}$ was measured by $17 i$ chemiluminescent $\mathrm{NO}-\mathrm{NO}_{2}-\mathrm{NO}_{x}$ analyzer (Thermo Scientific Co.). The $\mathrm{O}_{3}$ concentration was obtained from another site in the campus of HEBEU, which was a national observation site. This site was about $650 \mathrm{~m}$ southwest from the above observation site.

VOCs concentrations were observed using the instrument of
GC 5000 volatile organic compound online chromatographic monitor manufactured by AMA Instruments (Germany). The monitoring system has been described in detail in other studies (An et al., 2014; Zou et al., 2015). It includes five parts, i.e., GC 5000 VOC (two-stage enrichment), GC 5000 BTX (single-stage enrichment), DIM 200 dynamic calibrator, HG 300, and ZAG 300. GC 5000 VOC (AMA, Germany) online analyzer and GC 5000 BTX (AMA, Germany) online analyzer continuously measured $\mathrm{C}_{2}-\mathrm{C}_{6}$ hydrocarbons and $\mathrm{C}_{6}-\mathrm{C}_{12}$ hydrocarbons, respectively, with gas chromatographyflame ionization detector (GC-FID) systems. High-purity nitrogen was used as the carrier gas, and the Photochemical Assessment Monitoring Stations (PAMS) standard gas was diluted to $10^{-9}$ volume by DIM 200 for the following analysis. HG 300 is used to obtain $\mathrm{H}_{2}$ from electrolysis distilled water. ZAG 300 can remove organic impurities by catalytic decomposition of hydrocarbons. At first, sample gas was filtered by particulate filter and dehumidified by dehumidifier tube, then enriched by GC 5000 VOC and GC 5000 BTX, respectively. After that, it went through the focusing tube to the chromatographic column for separation. Finally, FID detector was used for detection. The instrument continuously sampled and analyzed VOCs with a temporal frequency of $1 \mathrm{~h}$. The instruments detect 56 VOCs species, including 29 alkanes, 10 alkenes, 16 aromatics and 1 alkyne.

\section{Quality Control}

QC was executed to ensure the accuracy of observation data in the study. In order to avoid the peak shift of the chromatogram, we adjusted the peak of the spectrum on the previous day according to the standard spectrum and export the results to ensure the accuracy of the data. PAMS standard gases were used to calibrate the instrument by multi-point every month. The MDLs (method detection limits) of all VOCs species measured ranged from $0.01-0.16 \mathrm{ppb}$. If the baseline is not stable, zero gas (nitrogen) is required to remove organic impurity. The mass concentration $\left(\mu \mathrm{g} \mathrm{m}^{-3}\right)$ of each compound was calculated from the mixing ratios in ppbv, using the following Eq. (1) (Wang et al., 2016):

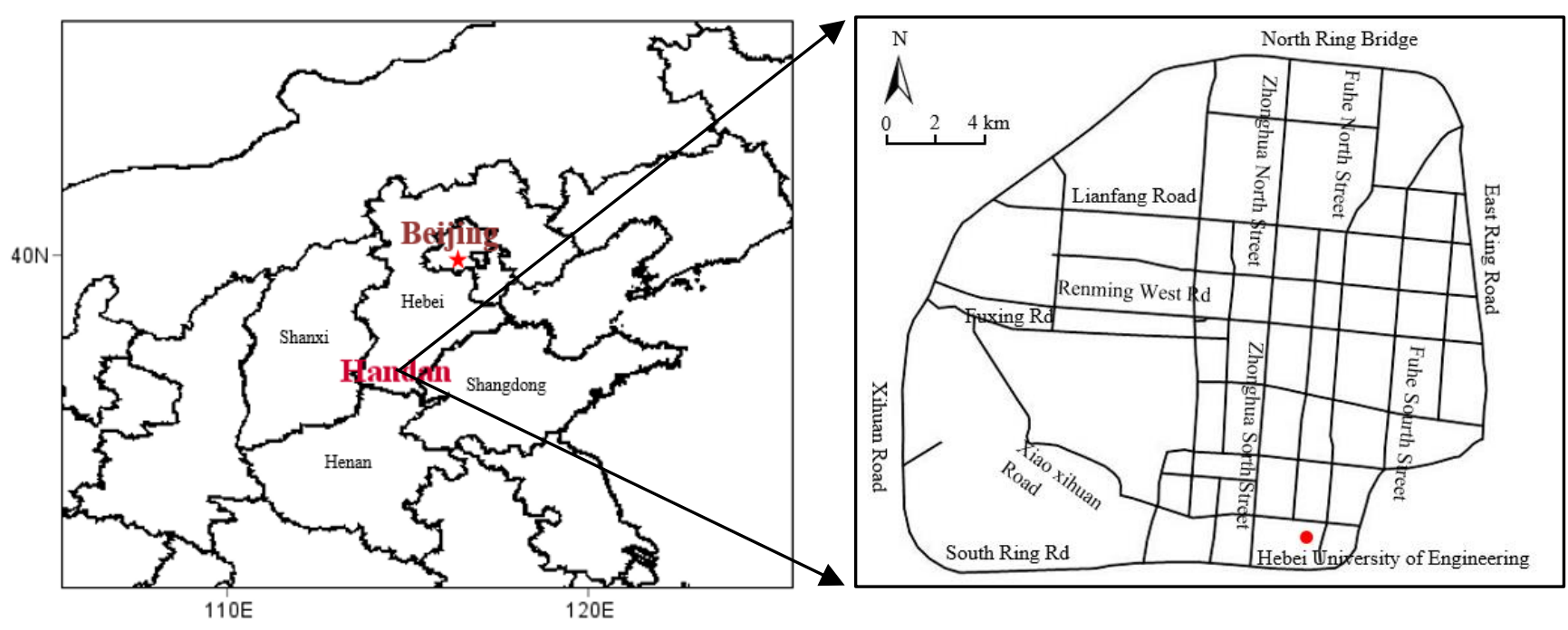

Fig. 1. Location of the observation site in Handan (the red dot is the location of monitoring station). 


$$
C_{i}=\frac{M_{i} \times C_{t}^{\prime}}{22.4} \times \frac{273.15}{273.15+T} \times \frac{B_{a}}{101.325}
$$

where $C_{i}$ is the concentration of VOCs species in $\mu \mathrm{g} \mathrm{m}^{-3}$. The $C_{i}{ }^{\prime}$ represents the volume concentration of corresponding VOCs species in ppb. $M_{i}$ is molecular weight. $T$ and $B_{a}$ represent the temperature $\left({ }^{\circ} \mathrm{C}\right)$ and atmospheric pressure $(\mathrm{kPa})$ during sampling period, respectively.

\section{RESULTS AND DISCUSSION}

\section{VOCs Concentrations}

Fig. 2 shows the mass concentrations of 56 VOCs species during observation period in Handan. The daily VOCs concentrations had a wide range in a year $\left(37.7-288.9 \mu \mathrm{g} \mathrm{m}^{-3}\right)$, with the average of $112.0 \pm 45.5 \mu \mathrm{g} \mathrm{m}^{-3}$. The concentration of 2-methylpentane $\left(11.3 \mu \mathrm{g} \mathrm{m}^{-3}\right)$ was the highest among the 29 alkane species, due to the high concentration of 2-

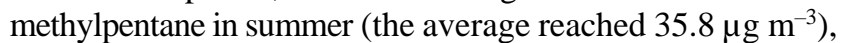
followed by $i$-pentane $\left(9.9 \mu \mathrm{g} \mathrm{m}^{-3}\right)$ and ethane $\left(8.7 \mu \mathrm{g} \mathrm{m}^{-3}\right)$. The BTEX had the highest concentration in aromatics $\left(16.2 \mu \mathrm{g} \mathrm{m}^{-3}\right)$, accounting for $61.8 \%$ in total aromatics. Toluene had the highest concentration $\left(5.6 \mu \mathrm{g} \mathrm{m}^{-3}\right)$ in all aromatics. In the observation period, the concentrations of the VOCs groups were listed as alkanes $>$ aromatics $>$ alkenes $>$ alkynes, of the concentrations of $63.1 \mu \mathrm{g} \mathrm{m}^{-3}, 26.2 \mu \mathrm{g} \mathrm{m}^{-3}$, $18.2 \mu \mathrm{g} \mathrm{m}^{-3}, 4.6 \mathrm{\mu g} \mathrm{m}^{-3}$, respectively.

Fig. 3(a) presents the seasonal variations of the 4 major VOCs. The concentrations of alkanes reached highest in summer and lowest in spring, and the concentrations in summer was $43.3 \%$ higher than in spring. Aromatic concentrations in autumn and winter were higher than that in the other two seasons. The concentrations of alkenes in winter was 2.5 times

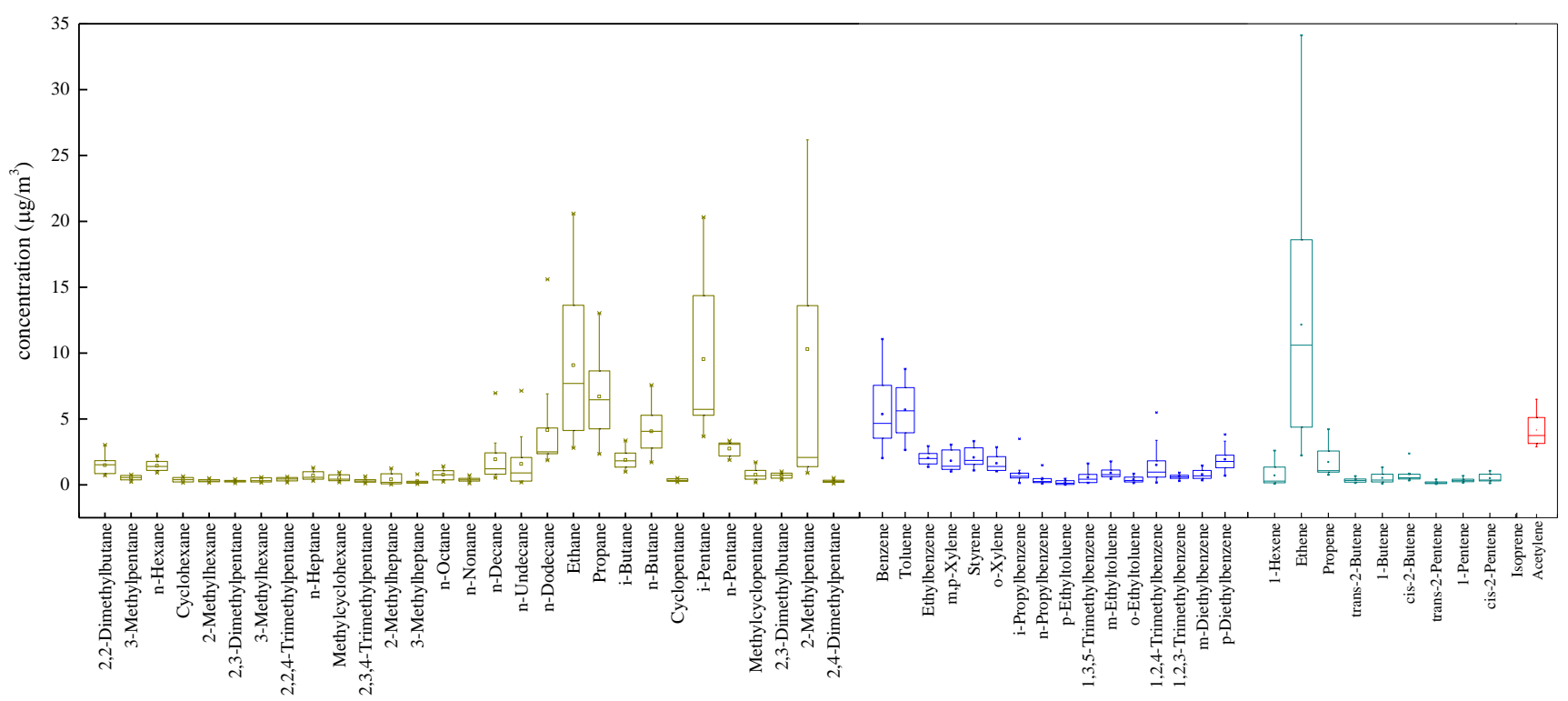

Fig. 2. Box plots of VOCs in Sep. 2017-Aug. 2018 in Handan $\left(\mu \mathrm{g} \mathrm{m}^{-3}\right)$ (the yellow, blue, green and red box chart represent alkanes, alkenes, aromatics, and alkynes, respectively).
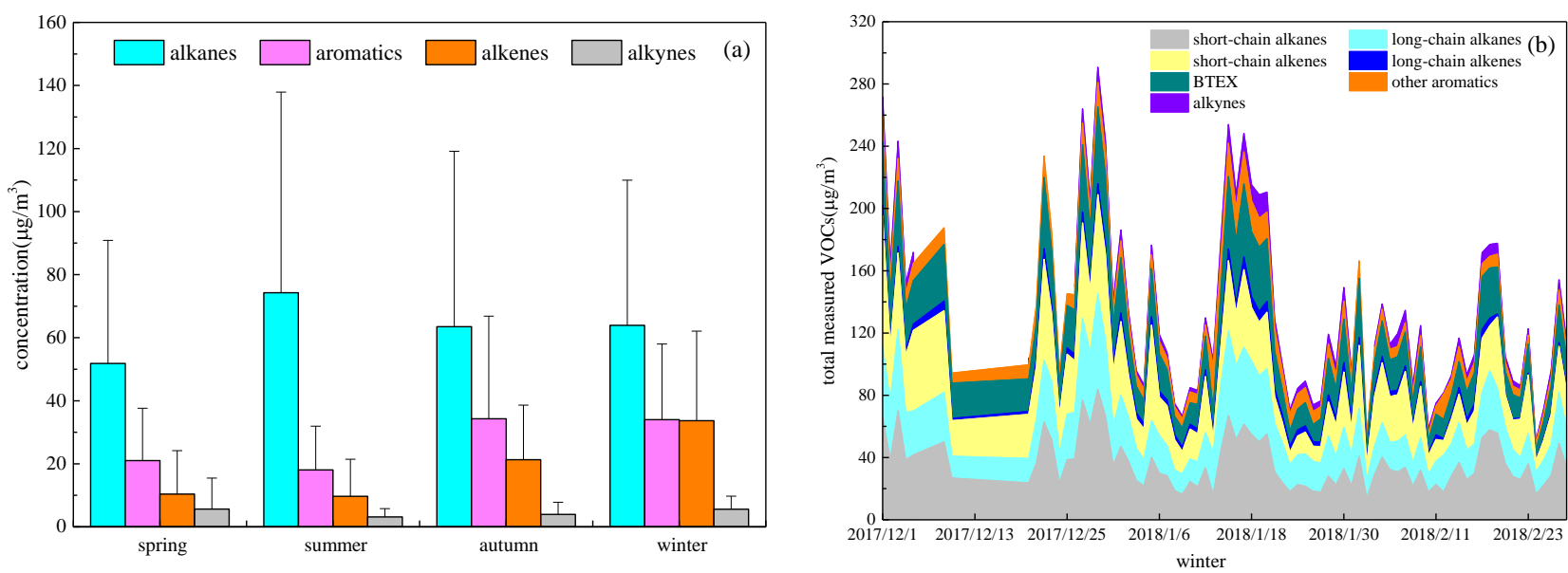

Fig. 3. (a) Seasonal variations of VOCs and their component concentrations. (b) VOCs and their component concentrations in winter: long-chain alkanes have a $\mathrm{C}>4$; other aromatics refers to aromatics except BTEX in this study. 
higher than that in summer. The total VOCs concentrations during observation as following trend: winter > autumn > summer $>$ spring. This was likely due to the variations of the ambient temperature, sunlight, the meteorological factors and the different emission strength of atmospheric pollutants during different seasons (Liu et al., 2016). The concentrations of VOCs in winter was highest, in which the short-chain alkanes $(\mathrm{C} \leq 4)$ accounted for $57.3 \%$ in total alkanes, and shortchain alkenes $(\mathrm{C} \leq 4)$ accounted for $88.4 \%$ of total alkenes. The long-chain alkene $(\mathrm{C}>4)$ concentrations were very low (3.9 $\mu \mathrm{g} \mathrm{m}^{-3}$ ) in winter (Fig. 3(b)). BTEX was the abundant group in aromatics, which accounted for $70.5 \%$ in aromatics with the average concentration of $24.2 \mu \mathrm{g} \mathrm{m}^{-3}$. Light alkanes and short-chain alkenes contributed most of VOCs in winter.
Table 1 presents the comparison of VOCs concentrations and the other reported cities (Liu et al., 2014; Chang et al., 2015; Wang et al., 2016; Hu et al., 2018; Bozkurt et al., 2018; Bari and Kindzierski, 2018; Yurdakul et al., 2018). VOCs concentrations in Handan were higher than Chinese cities such as Beijing, Jinan, and Hefei. However, the major VOCs species in the four seasons in Handan were similar to those in other Chinese cities, e.g., both alkanes and aromatics were the major species (except Shijiazhuang). The VOCs concentrations in winter of Shijiazhuang was 1.3 times higher than that in Handan. Solvent use for pharmaceutical and chemical were major VOCs sources in Shijiazhuang (Chang et al., 2015). Düzce and Calgary had lower VOCs concentrations than that in Handan. Major VOCs species in

Table 1. Comparison of VOCs concentrations in Handan and in other cities.

\begin{tabular}{|c|c|c|c|c|c|}
\hline City & Period & $\begin{array}{l}\text { VOCs } \\
\text { concentrations } \\
\left(\mu \mathrm{g} \mathrm{m}^{-3}\right)\end{array}$ & Major pollutants & $\begin{array}{l}\text { Instrument/ } \\
\text { detector }\end{array}$ & Reference \\
\hline \multirow[t]{4}{*}{ Handan, China } & Spring & 88.8 & $\begin{array}{l}i \text {-Pentane }(13.8 \%) \text {, } \\
\text { ethene }(7.8 \%), \\
\text { ethane }(7.7 \%), \\
\text { propane }(7.6 \%)\end{array}$ & GC 5000 & This work \\
\hline & Summer & 105.2 & $\begin{array}{l}\text { 2-Methylpentane }(34 \%) \text {, } \\
i \text {-pentane }(15.3 \%) \text {, } \\
\text { isoprene }(3.7 \%) \text {, } \\
\text { ethane }(3.2 \%)\end{array}$ & & \\
\hline & Autumn & 123.04 & $\begin{array}{l}\text { Ethene }(11.3 \%), \\
\text { ethane }(7.7 \%), \\
n \text {-dodecane }(7.7 \%), \\
\text { toluene }(5.7 \%)\end{array}$ & & \\
\hline & Winter & 136.6 & $\begin{array}{l}\text { Ethene }(17.8 \%) \text {, } \\
\text { ethane }(12.1 \%) \text {, } \\
\text { propane }(8.2 \%), \\
\text { benzene }(6.7 \%)\end{array}$ & & \\
\hline Beijing, China & Nov. 2014 & 27.6 & $\begin{array}{l}\text { Aromatics }(44.2 \%), \\
\text { alkanes }(40.9 \%)\end{array}$ & GC-MS & $\begin{array}{l}\text { (Wang et al., } \\
\text { 2016) }\end{array}$ \\
\hline $\begin{array}{l}\text { Shijiazhuang, } \\
\text { China }\end{array}$ & $\begin{array}{l}\text { Jan. 2014-Apr. } \\
2014\end{array}$ & 309.9 & $\begin{array}{l}\text { Aromatics }(31 \%) \text {, } \\
\text { halohydrocarbons }(30.7 \%)\end{array}$ & $\begin{array}{l}\text { Agilent } \\
\text { 6890N/5975B }\end{array}$ & $\begin{array}{l}\text { (Chang et al., } \\
\text { 2015) }\end{array}$ \\
\hline Jinan, China & $\begin{array}{l}\text { Jun. 2010-May } \\
2012\end{array}$ & 53.1 & $\begin{array}{l}\text { Cyclopentane }(14.3 \%), \\
i \text {-pentane }(9.7 \%), \\
\text { toluene }(9.5 \%), \\
\text { propane }(8.1 \%)\end{array}$ & airmo VOC & $\begin{array}{l}\text { (Liu et al., } \\
\text { 2014) }\end{array}$ \\
\hline Hefei, China & $\begin{array}{l}\text { Sep. 2016-Jan. } \\
2017\end{array}$ & 57.31 & $\begin{array}{l}\text { Toluene }(19.2 \%) \text {, chloroethene } \\
(14.2 \%) \text {, benzene }(14.0 \%) \text {, } \\
\text { dichloromethane }(13.4 \%), \\
1,2,4 \text {-trimethylbenzene }(13.3 \%)\end{array}$ & GC-MS & $\begin{array}{l}\text { (Hu et al., } \\
2018)\end{array}$ \\
\hline \multirow[t]{4}{*}{ Düzce, Turkey } & Spring & 13.5 & BTEX $(31.1 \%)$ & \multirow{4}{*}{$\begin{array}{l}\text { Thermal } \\
\text { desorber GC- } \\
\text { FID GC-MS }\end{array}$} & \multirow{4}{*}{$\begin{array}{l}\text { (Bozkurt et al., } \\
\text { 2018) }\end{array}$} \\
\hline & Summer & 11.6 & BTEX $(29.1 \%)$ & & \\
\hline & Autumn & 20.9 & BTEX (39\%) & & \\
\hline & Winter & 29.8 & BTEX $(50.4 \%)$ & & \\
\hline Bursa, Turkey & $\begin{array}{l}\text { Mar. 17, 2006- } \\
\text { May 10, } 2006\end{array}$ & 86.0 & $\begin{array}{l}\text { Toluene }(30 \%) \\
m, p \text {-xylene }(7.4 \%), \\
\text { benzene }(4.3 \%)\end{array}$ & $\begin{array}{l}\text { Agilent Model } \\
6890\end{array}$ & $\begin{array}{l}\text { (Yurdakul et } \\
\text { al., 2018) }\end{array}$ \\
\hline Calgary, Canada & 2010-2015 & 38.6 & $\begin{array}{l}\text { Ethane }(15.1 \%), \\
\text { propane }(12.3 \%), \\
n \text {-butane }(9.7 \%)\end{array}$ & GC-MS & $\begin{array}{l}\text { (Bari and } \\
\text { Kindzierski, } \\
\text { 2018) }\end{array}$ \\
\hline
\end{tabular}


Düzce were BTEX, but it still lower than BTEX concentrations in Handan. In the spring, the VOCs concentrations in Bursa was similar to that in Handan, while major VOCs pollutants were different (Table 1).

\section{Chemical Reactivity of VOC in Different Levels of $\mathrm{O}_{3}$ Pollution}

VOCs are important precursor of $\mathrm{O}_{3}$ formation in atmospheric environment. It is report that the $\mathrm{O}_{3}$ concentration and exceeding-standard days in 2018 obviously increased compared to those in 2017 (Ministry of Ecology and Environment of the People's Republic of China; http://www. mee.gov.cn/hjzl/). The $\mathrm{O}_{3}$ pollution levels in four seasons in Handan were shown in Fig. 4. $160 \mu \mathrm{g} \mathrm{m}^{-3}$ and $215 \mu \mathrm{g} \mathrm{m}^{-3}$ are limits of Grade II and III standard of National Ambient Air Quality Standard (NAAQS). We separate the days into clean period (defined as the maximum $8-\mathrm{h} \mathrm{O}_{3}$ concentration being less than $160 \mu \mathrm{g} \mathrm{m}^{-3}$ ), mild pollution (defined as the maximum 8- $\mathrm{h} \mathrm{O}_{3}$ concentration being between 160$215 \mathrm{\mu g} \mathrm{m}^{-3}$ ), medium pollution (defined as the maximum 8$\mathrm{h} \mathrm{O}_{3}$ concentration exceeding $215 \mu \mathrm{g} \mathrm{m}^{-3}$ ). It can be seen there was no excessive $\mathrm{O}_{3}$ in winter and a few days exceeded the standard in autumn. The mild pollution days account for $37 \%$ total days in spring. More than half of days were under $\mathrm{O}_{3}$ pollution in summer, with medium $\mathrm{O}_{3}$ pollution account for $20.7 \%$ in total days. Therefore, this study only discussed $\mathrm{O}_{3}$ pollution in summer.

$\mathrm{O}_{3}$ is an important product of photochemical reaction of VOCs and $\mathrm{NO}_{x}$ in atmosphere. In order to determine the role of VOCs in $\mathrm{O}_{3}$ photochemistry, we evaluated OFP for 55 VOCs (except acetylene). MIR (maximum incremental reactivity) considers the maximum number of $\mathrm{O}_{3}$ molecules generated by given VOCs species, as well as the interaction between kinetic reactivity and mixtures. The calculation Eq. (2) is given as below:

$$
\operatorname{OFP}(A)=\operatorname{MIR}(A) \times \mathrm{C}(A)
$$

where $C(A)$ represents the mass concentration $\left(\mu \mathrm{g} \mathrm{m}^{-3}\right)$ for species $A$. The MIR $\left(\mathrm{g}-\mathrm{O}_{3} \mathrm{~g}-\mathrm{VOCs}^{-1}\right)$ value for each species can be found by Carter (1994).

Prop-Equiv method put all VOCs species on a baseline to compare their reaction activity. In order to estimate the VOCs reaction activity according to their kinetic reactivity, Prop-Equiv concentration for each VOC species were calculated by following Eq. (3) (Lawrimore et al., 1995):

$$
\text { Prop-Equiv }(A)=\frac{C(A) \times \mathrm{KOH}(A)}{\mathrm{KOH}\left(\mathrm{C}_{3} \mathrm{H}_{6}\right)}
$$

where $\mathrm{KOH}(A)$ is the rate constant for the reaction of VOC species $A$ with $\mathrm{OH}$ radical; and $\mathrm{KOH}\left(\mathrm{C}_{3} \mathrm{H}_{6}\right)$ is the rate constant for $\mathrm{C}_{3} \mathrm{H}_{6}$ with $\mathrm{OH}$ radical. The specific values of rate constant for VOCs can be seen in references (Atkinson and Arey, 2003).

Fig. 5 shows the OFP and Prop-Equiv concentration of six VOCs groups during clean period, mild pollution and medium pollution days in summer in Handan. It can be seen that the rank of OFP and Prop-Equiv percentages of the six VOCs groups have different change under three pollution level. OFP followed the order of long-chain alkanes > long-chain alkenes $>$ short-chain alkenes $>$ other aromatics $>$ BTEX > short-chain alkanes. Prop-Equiv concentrations were longchain alkenes $>$ long-chain alkanes $>$ BTEX > short-chain alkenes $>$ other aromatics $>$ short-chain alkanes. It should be noted that the OFP of long alkanes were the highest among the six VOCs groups, partially due to that 2-methylpentane concentration was quite high, with $28.3-37.5 \%$ of total VOCs concentrations (Fig. 6). Therefore, long alkanes and alkenes play an important role in $\mathrm{O}_{3}$ formation in summer in Handan.

The OFP of long-chain alkenes and short-chain alkenes in medium pollution were $7.3 \mu \mathrm{g} \mathrm{m}^{-3}$ and $6.3 \mu \mathrm{g} \mathrm{m}^{-3}$ higher than that in clean period, respectively. The OFP of shortchain alkenes and other aromatics were higher in medium pollution than in other two conditions. In especially, the OFP of short-chain alkenes were $45.3 \mu \mathrm{g} \mathrm{m}^{-3}$. But OFP of long-chain alkanes in $\mathrm{O}_{3}$ pollution days were lower than the other two pollution levels. The proportion of Prop-Equiv concentration of long-chain alkenes and BTEX in medium pollution was higher than that in clean period. The results of Prop-Equiv method are basically consistent with OFP. Thus it can be seen alkenes and other aromatics were more important in $\mathrm{O}_{3}$ medium days.

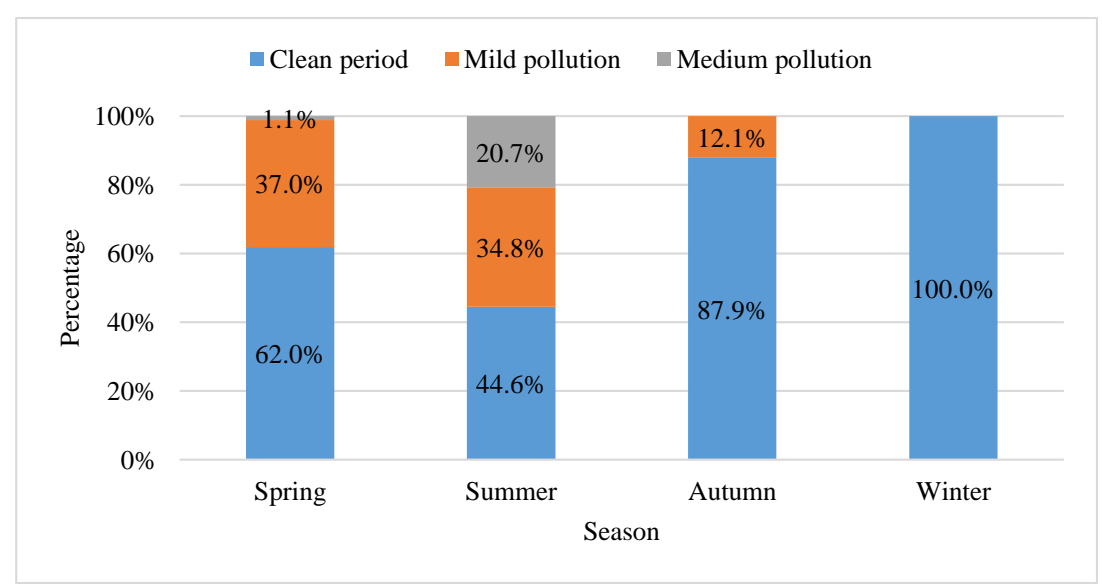

Fig. 4. The percentages of $\mathrm{O}_{3}$ pollution days in the four seasons in Handan. 
(a)

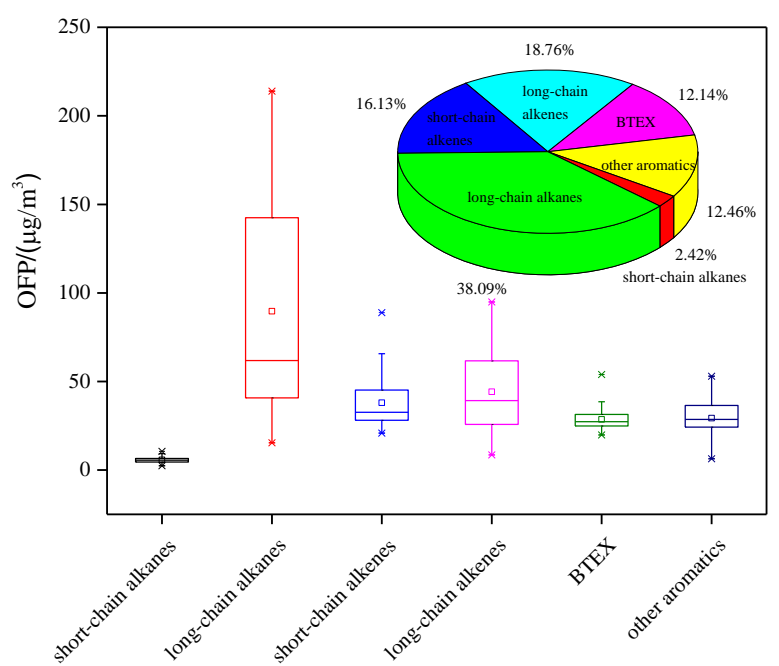

(b)

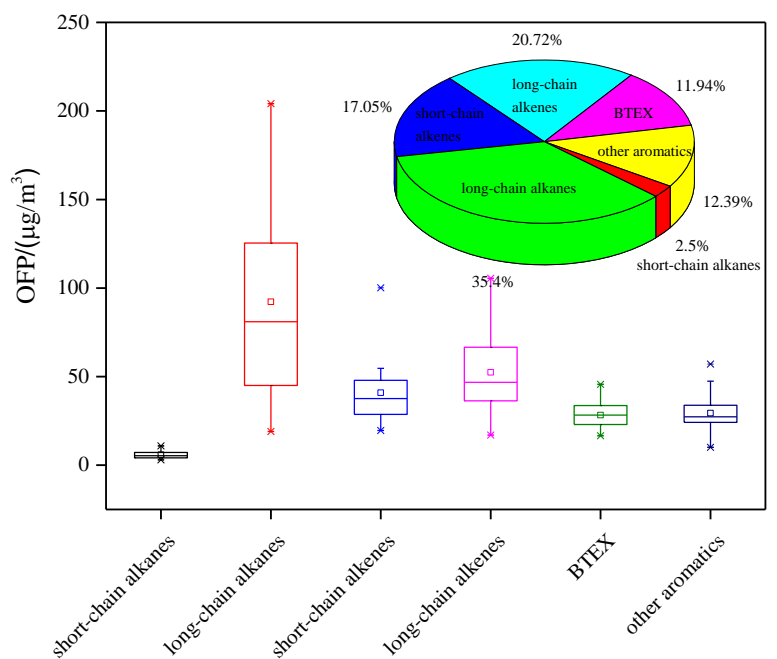

(c)

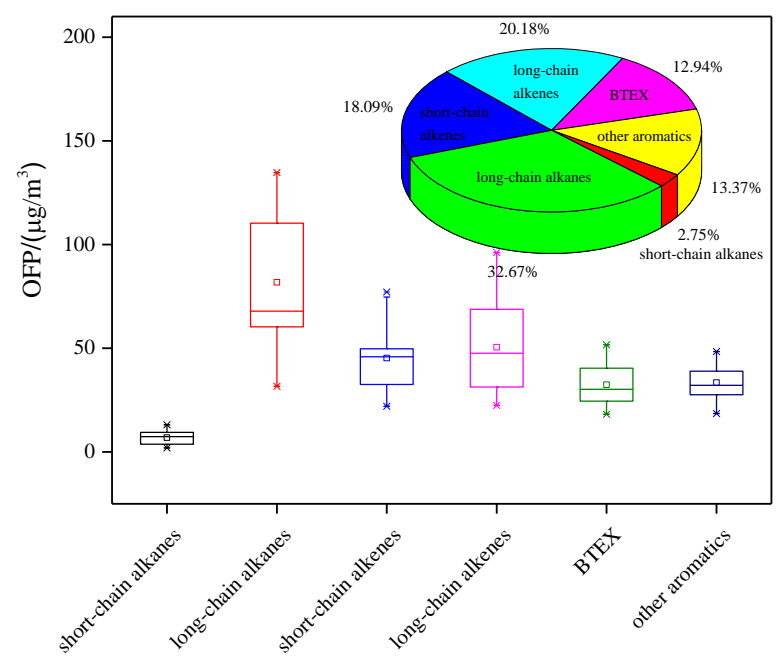

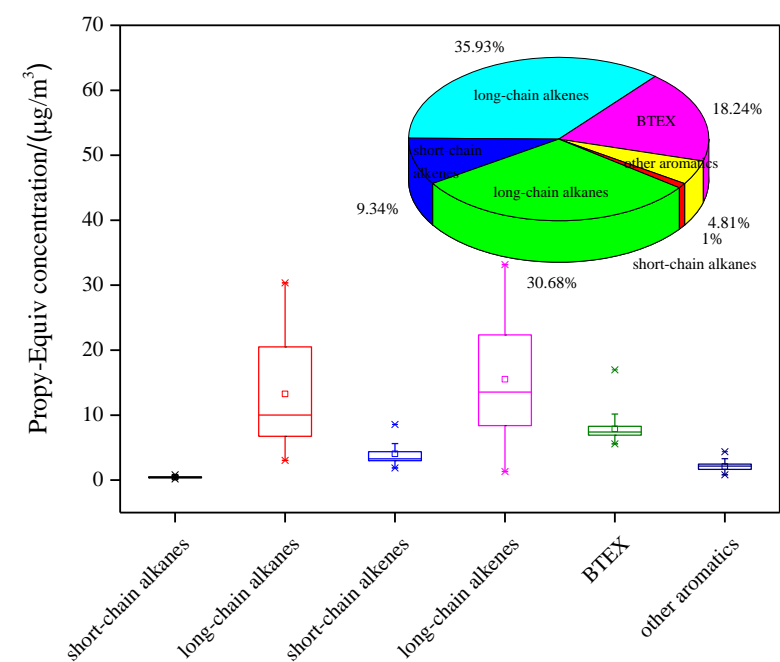
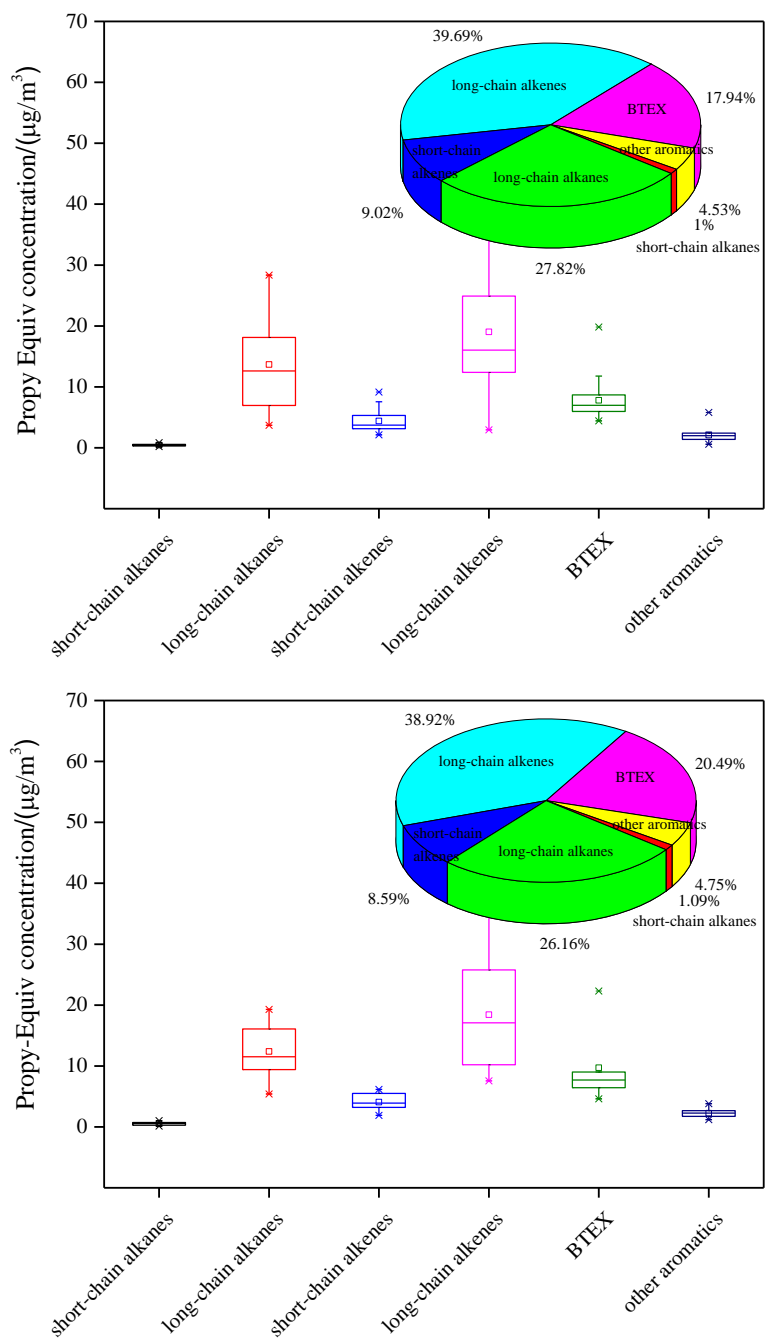

Fig. 5. Chemical reactivity of major VOC components in different $\mathrm{O}_{3}$ pollution level in Handan: (a) clean period, (b) mild pollution, and (c) medium pollution.

Prop-Equiv concentrations and OFP of major VOCs as well as their concentrations under different $\mathrm{O}_{3}$ pollution levels in summer in Handan were presented in Fig. 6. Isoprene, 2methylpentane and $o$-xylene have high Prop-Equiv concentrations with strong chemical reaction activity in summer. 2-Methylpentane, isoprene, ethene and $i$-pentane are major contributors to form $\mathrm{O}_{3}$. In particular, the concentration of isoprene accounted for $3.4-4.1 \%$ of VOCs, while its OFP 
(a)

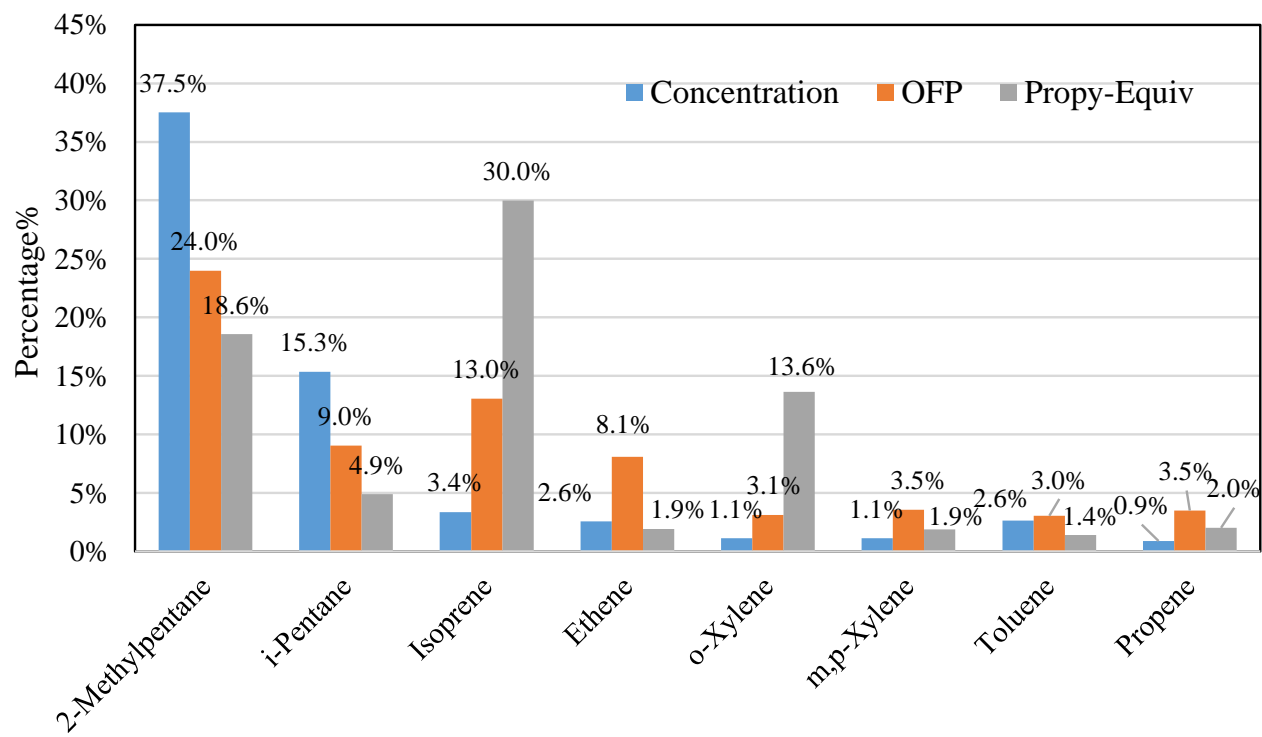

(b)

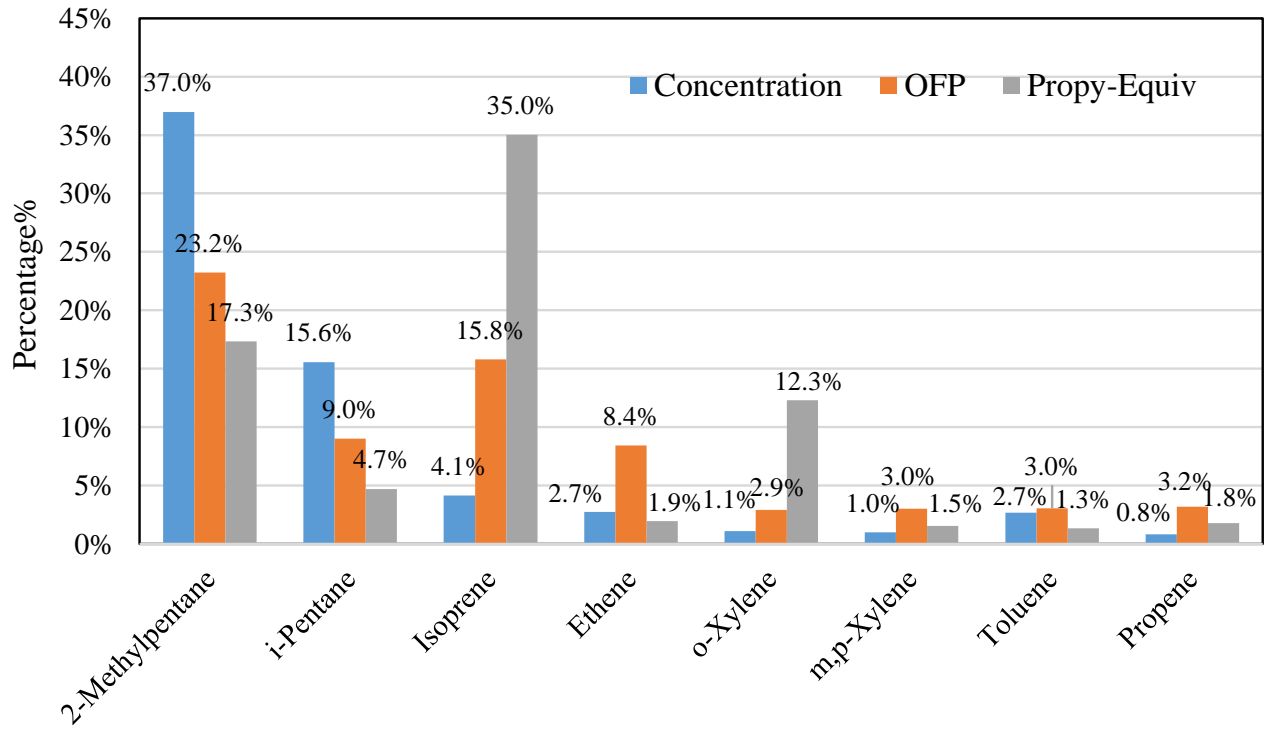

(c)

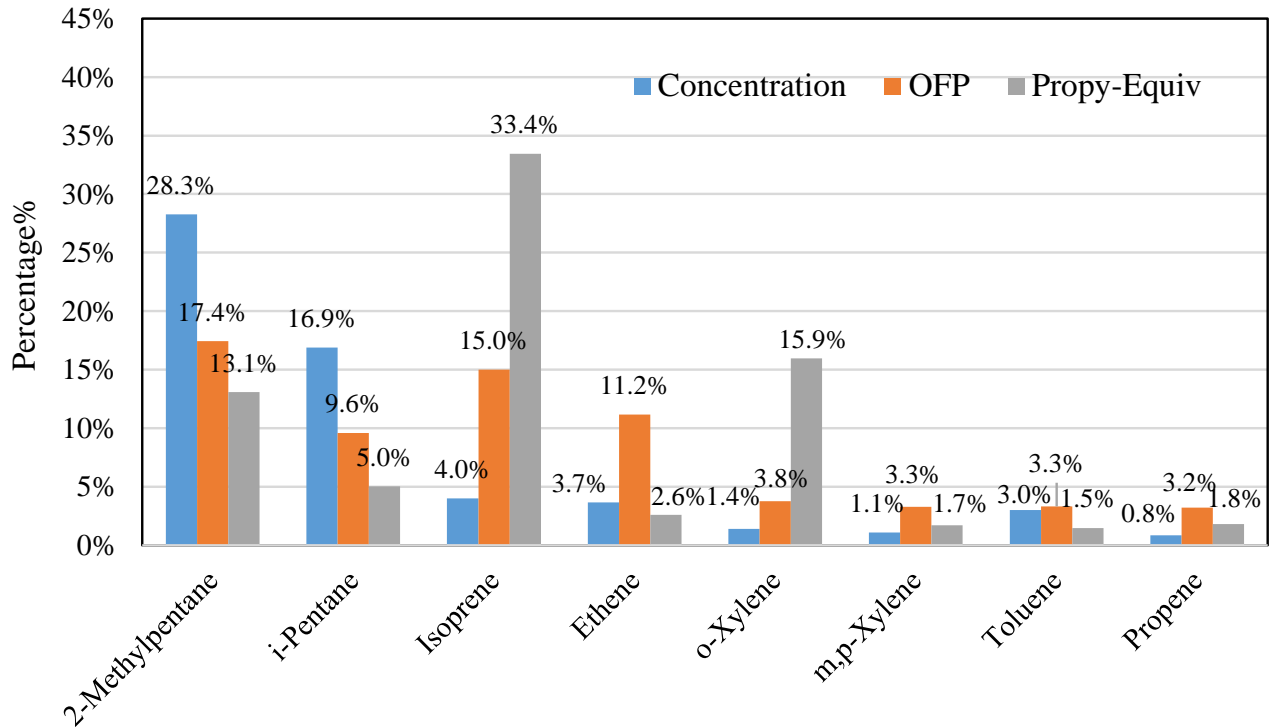

Fig. 6. Percentages of the concentrations, OFP and Prop-Equiv concentrations of major VOCs under different levels of $\mathrm{O}_{3}$ pollution in Handan: (a) clean period, (b) mild pollution, and (c) medium pollution. 
accounted for $30-35 \%$ in total OFP. Toluene and xylene were the top contributors of $\mathrm{O}_{3}$ formation among aromatic, which was consist with previous work (Tan et al., 2012; Kumar et al., 2017). It can be seen that the OFP of $i$-pentane, ethene and $o$-xylene were lower in clean period than that in mild pollution days and medium pollution days, while 2methylpentane was the opposite. The OFP for VOCs in medium pollution $\left(250.4 \mu \mathrm{g} \mathrm{m}^{-3}\right)$ was not significantly higher than that in mild pollution $\left(249.2 \mu \mathrm{g} \mathrm{m}^{-3}\right)$. It implies that VOCs were not the main factor of medium $\mathrm{O}_{3}$ formation in summer. $\mathrm{NO}_{x}$ also had important effect on $\mathrm{O}_{3}$ concentration, which verifies the assumption in the following sections.

\section{Regional $\mathrm{O}_{3}$ Formation Mechanism}

The concentration variations and hourly change rates of $\mathrm{O}_{3}$ can better illustrate diurnal variations and formation processes of $\mathrm{O}_{3}$. The value of change rate can be calculated using following Eq. (4):

$$
\frac{d[X]}{D t}=[X]_{t}-[X]_{t-1}
$$

where $[X]_{t}$ is the concentration of $\mathrm{O}_{3}$ at time $t,[X]_{t-1}$ represents the concentrations for the last hour before time $t$.

The ratio of VOCs and $\mathrm{NO}_{x}$ can be used to qualitatively evaluate the relationship between $\mathrm{O}_{3}$ and its precursors (VOCs and $\mathrm{NO}_{x}$ ). Assessing whether the city is VOC-sensitive or $\mathrm{NO}_{x}$-sensitive is necessary to effectively control $\mathrm{O}_{3}$ pollution. Under typical atmospheric conditions, the reaction rate constants between $\mathrm{NO}_{x}$ and $\mathrm{OH}\left(1.7 \times 10^{10}\right)$ is 5.5 times that of VOC and $\mathrm{OH}\left(3.1 \times 10^{9}\right)($ Tang et al., 2006). When the emission ratio of $\mathrm{VOC} / \mathrm{NO}_{x}$ is 5.5, photochemical reactions of $\mathrm{O}_{3}$ are in equilibrium (Chen et al., 2019). For the ratio to be valid, the VOCs concentration must be expressed on per-carbon-atom basis (Sinha et al., 2012). Fig. 7 shows the diurnal variation of $\mathrm{O}_{3}$ concentration, $\mathrm{VOC} / \mathrm{NO}_{x}$ and $\mathrm{VOC}(\mathrm{OFP}) / \mathrm{NO}_{x}$ ratios, change rate of $\mathrm{O}_{3}$ in four seasons
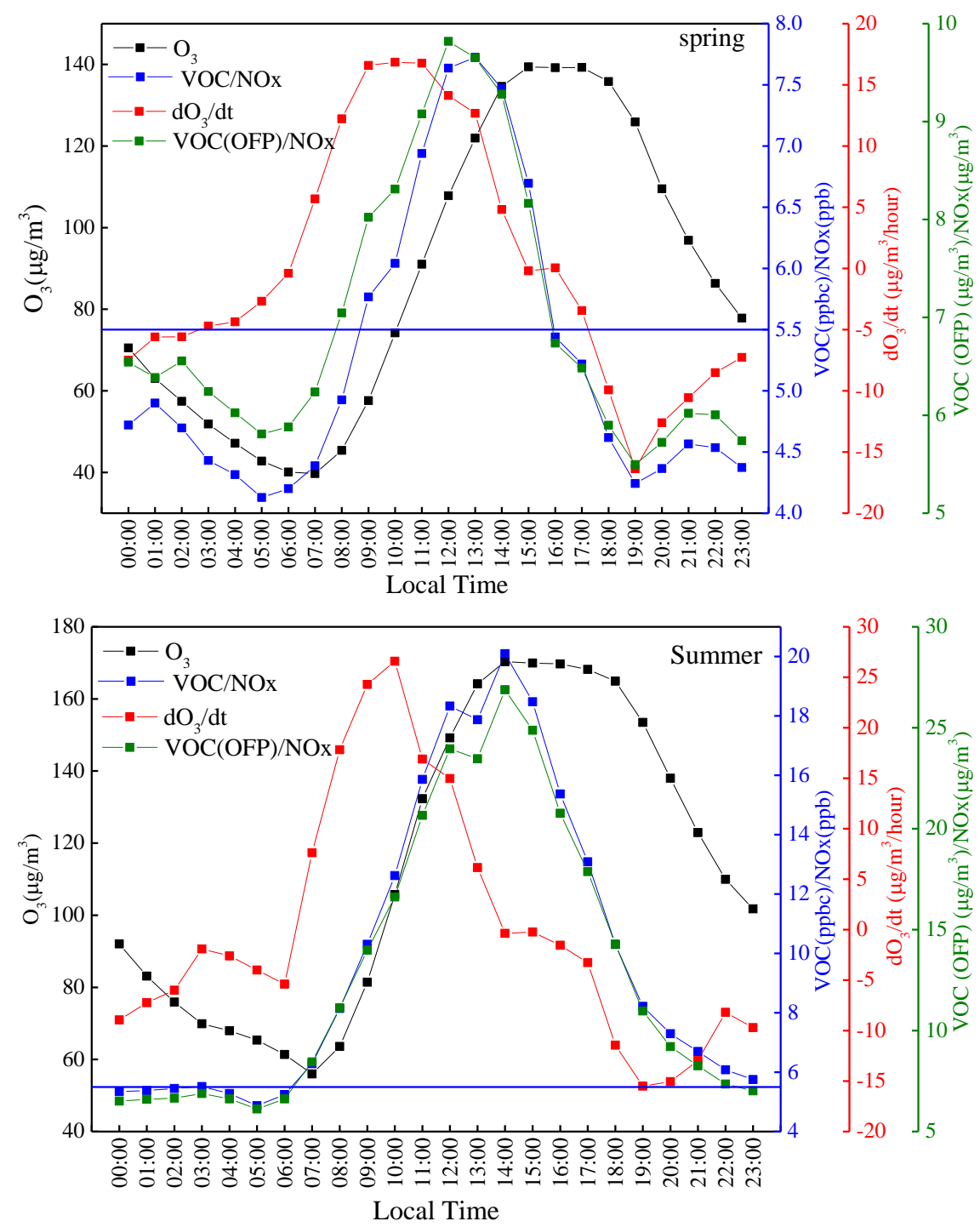

Fig. 7. The diurnal variation of $\mathrm{O}_{3}$ concentration, $\mathrm{VOC} / \mathrm{NO}_{x}$ and $\mathrm{VOC}(\mathrm{OFP}) / \mathrm{NO}_{x}$ ratios, change rate of $\mathrm{O}_{3}$ in different seasons in Handan (the blue line is the $\mathrm{VOC}(\mathrm{ppbc}) / \mathrm{NO}_{x}(\mathrm{ppb})$ ratio of 5.5:1). 

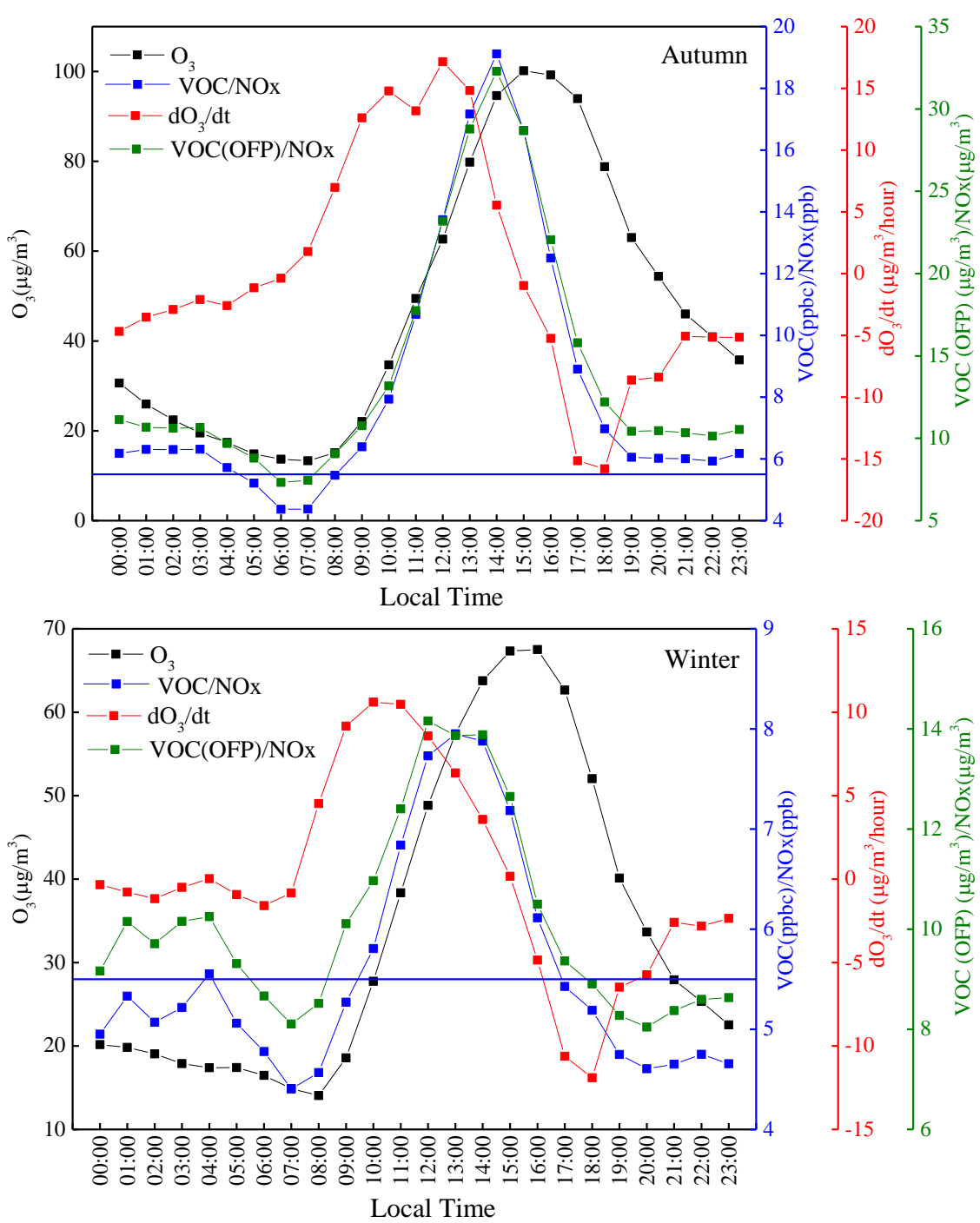

Fig. 7. (continued).

for one year. In spring and winter, the $\mathrm{VOC} / \mathrm{NO}_{x}$ ratios were more than 5.5 from 10:00 to 16:00 LT, and the ratio of the other time of the day were less than 5.5. This illustrates that $\mathrm{O}_{3}$ formation mainly occurred under the VOC-sensitive regime. At this time, the reaction rate of $\mathrm{NO}_{2}$ with $\mathrm{OH}$ is higher than VOCs with $\mathrm{OH}$, and the reaction can remove $\mathrm{OH}$ from VOC oxidation cycle. Under this condition, reducing $\mathrm{NO}_{x}$ emission will bring more $\mathrm{O}_{3}$. In summer, the ratio reached a relatively high level from 07:00 to 22:00 LT, with the average of 12:1. Except the period from 05:00 to 08:00 LT, the ratio was greater than 5.5 in autumn with average of 9 . In those two seasons the $\mathrm{O}_{3}$ formation was under the $\mathrm{NO}_{x}$ sensitive regime, that is, reducing $\mathrm{NO}_{x}$ is beneficial to the reaction of peroxide radicals $\left(\mathrm{HO}_{2}\right.$ and $\left.\mathrm{RO}_{2}\right)$ and hinders the formation of $\mathrm{O}_{3}$.

The maximum ratio of $\mathrm{VOC} / \mathrm{NO}_{x}$ and $\mathrm{VOC}(\mathrm{OFP}) / \mathrm{NO}_{x}$ appeared around 13:00 LT in each season and their trends are similar. The $\mathrm{VOC}(\mathrm{OFP}) / \mathrm{NO}_{x}$ ratio is 1.5 times of $\mathrm{VOC} / \mathrm{NO}_{x}$ in the four seasons. We also find that the ratio of $\mathrm{VOC}(\mathrm{OFP}) / \mathrm{NO}_{x}$ and $\mathrm{VOC} / \mathrm{NO}_{x}$ will decrease with the increase of $\mathrm{O}_{3}$ pollution frequency. The $\mathrm{VOC}(\mathrm{OFP}) / \mathrm{NO}_{x}$ ratio is 1.3 times of $\mathrm{VOC} / \mathrm{NO}_{x}$ in summer. Fig. 7 presents the change rate of $\mathrm{O}_{3}$ began to increase at 07:00 LT, reaching a maximum three hours later. At about 15:00 LT, the $\mathrm{O}_{3}$ concentrations reached the maximum in all the four seasons, which is a typical process of $\mathrm{O}_{3}$ accumulation in atmosphere. The $\mathrm{O}_{3}$ concentration is much higher in summer than that in other three seasons, especially from 12:00 to 18:00 LT. In the high- $\mathrm{O}_{3}$ episode, the $\mathrm{O}_{3}$ chemistry was under the $\mathrm{NO}_{x^{-}}$ sensitive regime, which is similar to previous studies in Guangzhou (Zou et al., 2015) and Pearl River Delta region (Li et al., 2013).

Fig. 8 shows diurnal variation of $\mathrm{VOC} / \mathrm{NO}_{x}$ ratio during clean period, mild pollution and medium pollution days in summer. The diurnal variation trend and value of $\mathrm{VOC} / \mathrm{NO}_{x}$ ratio in mild pollution and medium pollution days were similar. The $\mathrm{VOC} / \mathrm{NO}_{x}$ in clean period were highest in the three pollution levels, however, the $\mathrm{O}_{3}$ concentration was much higher in medium pollution days than those in clean period and mild pollution days. Considering the conclusions with OFP of VOCs, the OFP in the three pollution levels have no significant difference. $\mathrm{NO}_{x}$ average concentration 


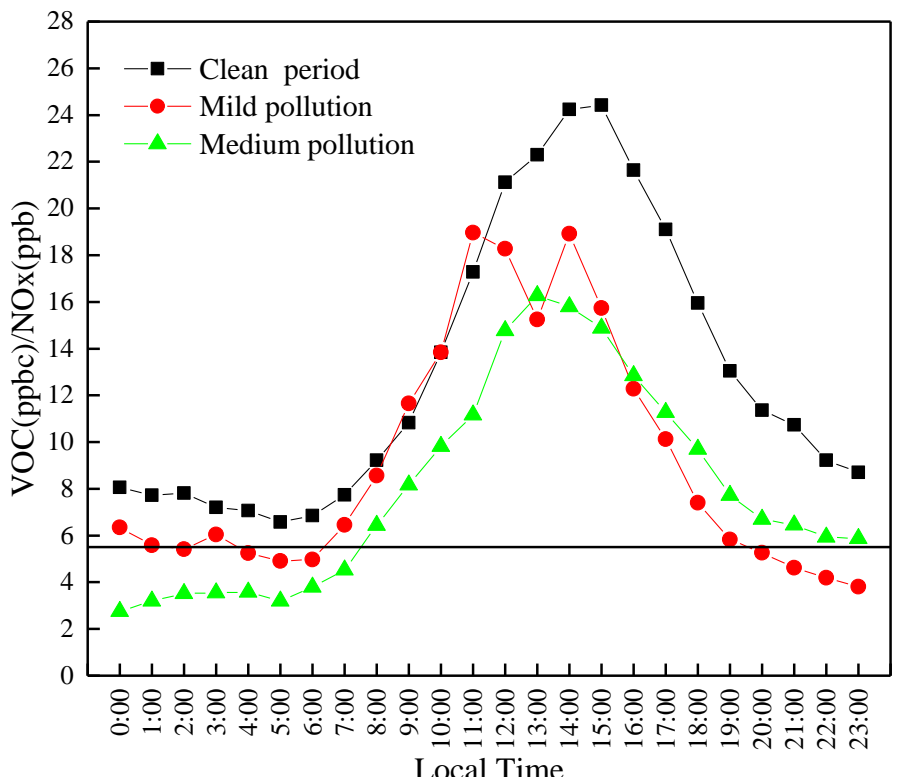

Fig. 8. The diurnal variation of $\mathrm{VOC}(\mathrm{ppbc}) / \mathrm{NO}_{x}(\mathrm{ppb})$ ratio in different $\mathrm{O}_{3}$ pollution levels in Handan (the black line is the VOC $(\mathrm{ppbc}) / \mathrm{NO}_{x}(\mathrm{ppb})$ ratio of 5.5:1).

in medium pollution days were $14 \mu \mathrm{g} \mathrm{m}^{-3}$ higher than clean period. Therefore, it can be concluded that $\mathrm{NO}_{x}$ and VOCs dominated the $\mathrm{O}_{3}$ formation, especially in medium pollution. Whether there is regional $\mathrm{O}_{3}$ transmission remains to be proved.

\section{Ambient Ratios: Photochemical Characteristics and Sources}

The change in concentration ratio of special hydrocarbon can reflects their atmospheric photochemical processes, and effect of atmospheric physical transmission is eliminated by their ratio (Nelson and Quigley, 1983). The photochemical age of air masses can be described by the measured ratio between benzene and toluene. Using the observed ratio, the photochemical age of sampled air masses was estimated as following Eq. (5) (Roberts et al., 1984):

$$
\begin{aligned}
t & =\frac{1}{[\mathrm{OH}]\left(K_{\text {toluene }}-K_{\text {benzene }}\right)} \\
& \times\left[\ln \left(\left[\frac{[\text { toluene }]}{[\text { benzene }]}\right]_{t=0}\right)-\ln \left(\frac{[\text { toluene }]}{[\text { benzene }]}\right)\right]
\end{aligned}
$$

where $[\mathrm{OH}]$ is the 24-h average concentration of $\mathrm{OH}$, i.e., 3 $\times 10^{6}$ molecules $\mathrm{cm}^{-1} \mathrm{~s}^{-1}$. $\mathrm{K}_{\text {toluene }}$ and $\mathrm{K}_{\text {benzene }}$ represent the coefficients for the reaction of $\mathrm{OH}$ with toluene and benzene, the values were $5.63 \times 10^{-12}$ molecules $\mathrm{cm}^{-1} \mathrm{~s}^{-1}$ and $1.22 \times$ $10^{-12}$ molecules $\mathrm{cm}^{-1} \mathrm{~s}^{-1}$, respectively (Atkinson and Arey, 2003). [toluene]/[benzene] is ratio between toluene and benzene of observation. The ratio ([toluene]/[benzene $\left.]_{t=0}\right)$ is the initial concentration ratio. The concentrations of toluene and benzene in ratio [toluene]/[benzene $]_{\mathrm{t}=0}$ were estimated from the $5^{\text {th }}$ percentile of the observation at 07:00 LT in this study (Li et al., 2019).
The assumption that the source of anthropogenic VOCs removal is governed by reactions with $\mathrm{OH}$ implies that any two compounds with the similar $\mathrm{OH}$ rate coefficient must be well correlated (de Gouw et al., 2005). As shown in Fig. 9(a), the scatter plot of benzene versus acetylene painted by photochemical age shows that a good correlation of benzene and acetylene with correlation coefficient of 0.7 . The ethylbenzene and acetylene are positively correlated (Fig. 9(b)), however, the correlation coefficient $(r=0.54)$ is less than that of benzene and acetylene. We also found that the ethylbenzene/acetylene ratio decreased with increasing photochemical age (slope $=-8.06$ ), while the ratio of benzene and acetylene increased with photochemical age (slope $=2.1$ ). The reason is that the removal efficiency of ethylbenzene in the atmosphere is faster than toluene, the removal rate of ethylbenzene is about 6 times larger than benzene. The scatter plot of propane versus $n$-butane and $i$-butane were also colored by photochemical age (Figs. 9(c) and 9(d)). The two figures show good correlation of both $n$-butane and $i$-butane with propane, especially correlation coefficient of $n$-butane with propane is 0.93 , indicating $n$-butane and propane have similar source. Propane and butane are main components of liquefied petroleum gas (LPG)/nature gas (NG) (McCarthy et al., 2013; Baudic et $a l ., 2016)$. The $n$-butane and $i$-butane have similar reaction rates with the $\mathrm{OH}$ radicals, the ratio of these pair species indicated different sources (Huang et al., 2018). Previous studies have shown that $i$-butane $/ n$-butane ratio varied according to sources: $\sim 0.2-0.3$ for urban vehicular exhaust, 0.46 for LPG, $\sim 0.6-1$ for NG (Barletta et al., 2002; Russo et al., 2010). Our result indicated the slope of $i$-butane $/ n$-butane (0.23-0.47) within the range of emission mainly from vehicular exhaust and LPG (Fig. 10(a)), this is relative to the actual situation, LPG is the fuel for taxis and private cars in Handan. As shown in Fig. 10(b), the slope of the correlation 

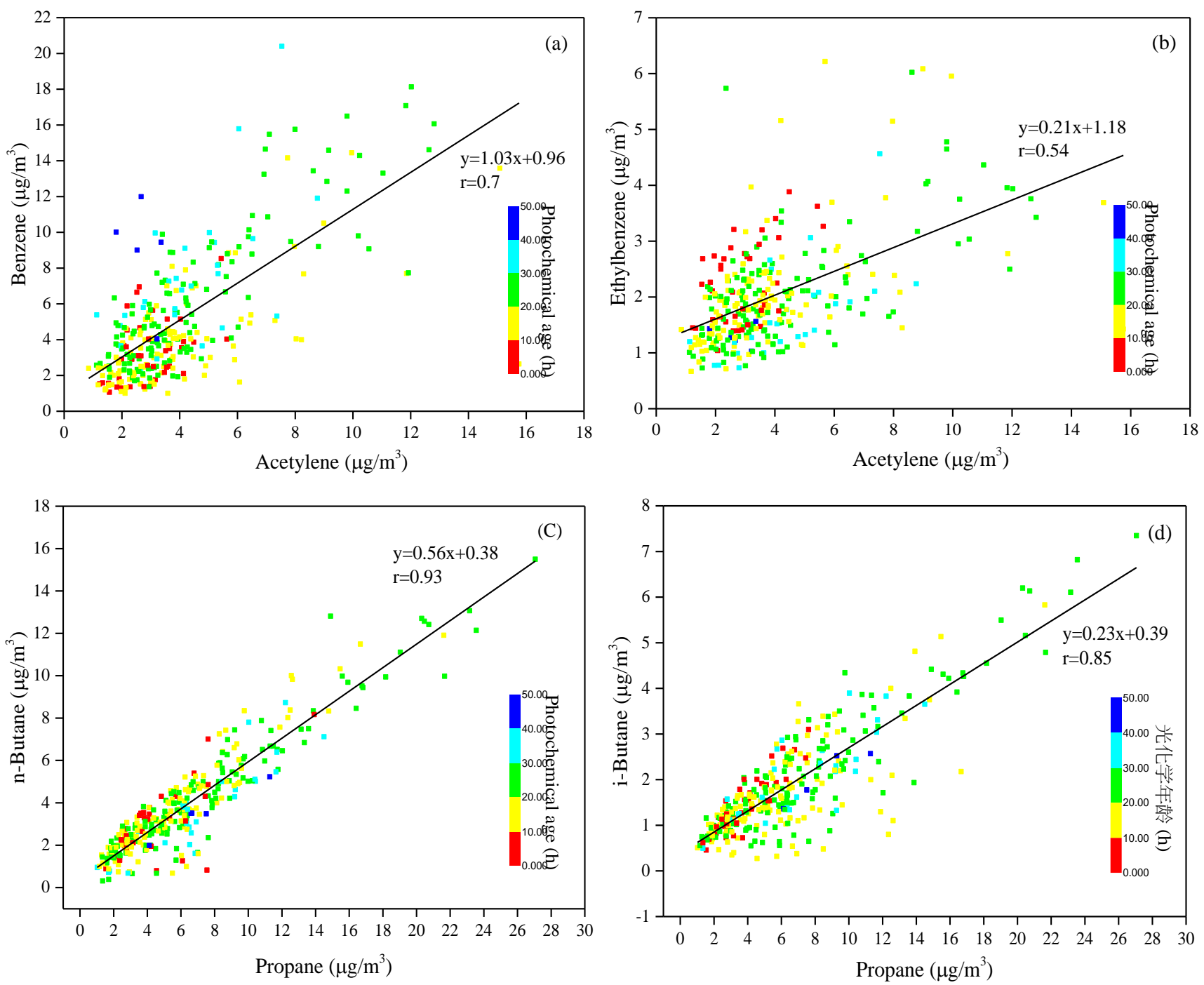

Fig. 9. Scatter plots of acetylene versus (a) benzene and (b) ethylbenzene, and propane versus (c) $n$-butane and (d) $i$-butane. The scatter points are painted by photochemical age.
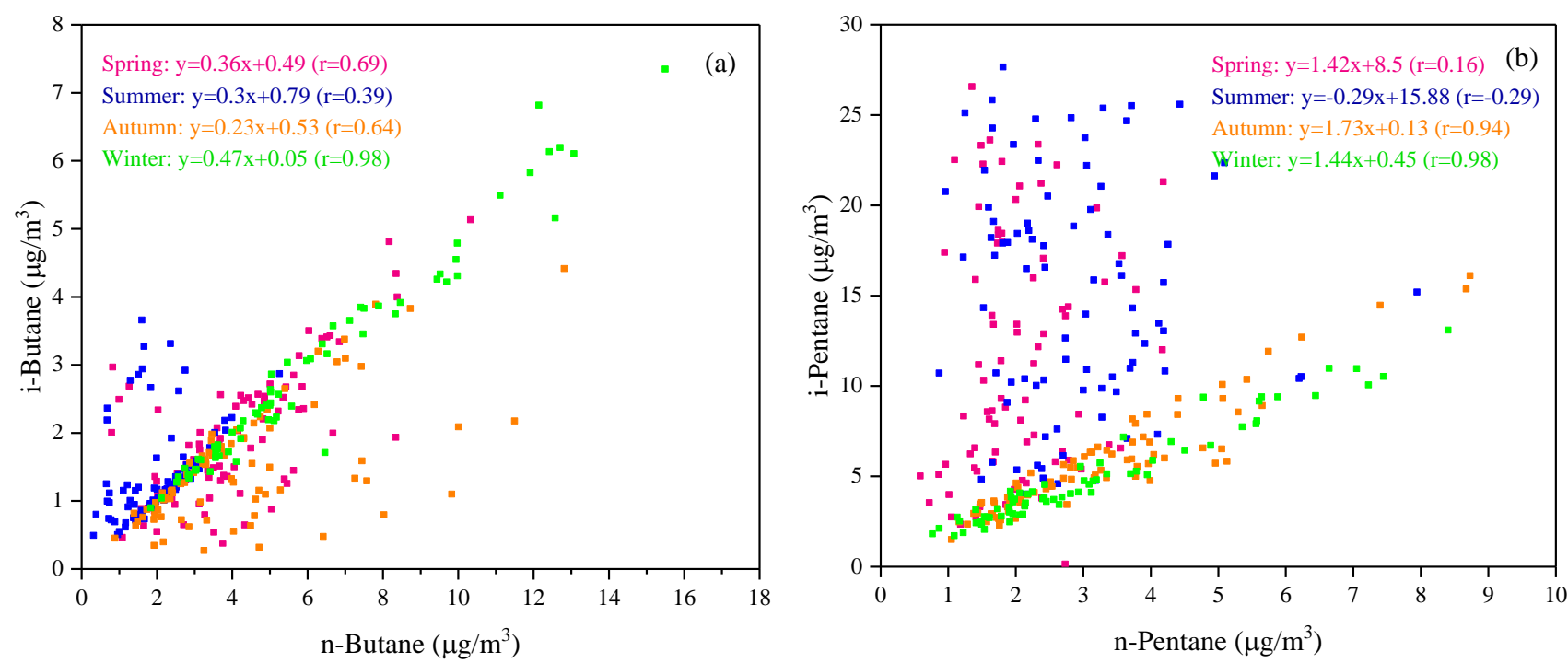

Fig. 10. Correlations between compounds with similar atmospheric lifetimes: (a) n-butane versus $i$-butane, and (b) $n$-pentane versus $i$-pentane. 
of $i$-pentane and $n$-pentane $(-0.29)$ in summer was quite different other seasons (1.42-1.73), so we speculated that pentane were from liquid gasoline source in spring, autumn and winter in term of the ratio ( 1.5-3) (Russo et al., 2010).

\section{Source Apportionment}

PCA, as one of the receptor models, is applied for solving a bilinear model by analyzing multivariate dataset. PCA is based on correlation matrix analysis to find the independent factors in large number of components. The number of principal components depends on the retained variance. The calculation procedures of PCA can refer to Meng et al. (2016). In recent years, many researches applied this model to analyze VOCs sources (Chang et al., 2009; An et al., 2014; Franco et al., 2015; Meng et al., 2016).

The top 20 VOCs species account for more than $80 \%$ of total VOCs concentrations in this study; therefore, we select the top 20 kinds of VOCs to analyze source by statistical software SPSS 21 in four seasons. The Kaiser-Meyer-Olkin (KMO) index detected by input data was more than 0.8 and the sphericity test of Bartlett is 0. It indicates that the PCA model can be applied in this study. The factors were extracted with eigenvalue more than 1. Tables S1-S4 list the results of PCA model in four seasons. The cumulative variances of factors were $72.5 \%$ (spring), 76.4\% (summer), 72\% (autumn) and $81 \%$ (winter), which covered most of the information of data.

Table 2 show the source apportionment for VOCs in different seasons. Table $\mathrm{S} 1$ shows that there are five factors in spring. Factor 1 is identified as butane, propane, and $n$-pentane, 2-methylpentane and toluene, $m, p$-xylene with obvious loading of $0.6-0.9$. The butane and propane are released from LPG/NG (McCarthy et al., 2013; Lyu et al., 2015), Handan implemented the project of replacing coal with gas from 2017. Therefore, the usage and emission of LPG/NG began to increase. While toluene, $m, p$-xylene and 2-methylpentane are likely to be from solvent use. Toluene and xylene are widely used as in printing, furniture and adhesives (Buzcu and Fraser, 2006; Ling et al., 2011), and long-chain alkane may be from industrial production (Shao et al., 2016). The variance of vehicle emission contributed $27 \%$. For Factor 2, ethene, ethane and benzene were weighted relatively higher, the three compounds are important markers of combustion sources (Liu et al., 2008; Hui et al., 2019). While benzene originate from automobile exhaust in urban area. Therefore, Factor 2 can be regard as automobile exhaust about combustion. Factor 3 only consists of $n$-dodecane and $p$-diethylbenzene, the compounds containing $>10$ carbon atoms are from diesel vehicle (Liu et al., 2008). Factor 4 includes $n$-hexane, styrene and $i$-pentane. $n$-Hexane and $i$ pentane could be attributed to temperature-related source or artefacts (Leuchner et al., 2015; Baudic et al., 2016), and styrene may originate from petrochemical plants and solvent usage (Chang et al., 2009). Therefore, Factor 4 represents industrial source. For Factor 5, 2,2-dimethylbutane and $m$ diethylbenzene is identified as solvent in industrial manufacture (An et al., 2014; Baudic et al., 2016).

The main sources of factor analysis in summer, autumn and winter are listed in Tables S2-S4. There are six VOC sources and variance in summer: Factor 1 is gasoline evaporation (20.7\%); Factor 2 is solvent use (18.7\%); Factor 3 is automobile exhaust (14.5\%); Factor 4 is industrial production $(10.9 \%)$; Factor 5 is diesel vehicle $(6.3 \%)$; Factor 6 is biogenic emission (5.5\%). Five sources are found in winter: Factor 1 is solvent use and fuel volatilization (36.7\%); Factor 2 is gasoline vehicle emission $(15.5 \%)$; Factor 3 is industrial (8\%); Factor 4 is diesel vehicle (6.6\%); Factor 5 is biomass combustion $(5.1 \%)$. In winter there are four primary sources: Factor 1 is LPG and solvent use (36.5\%); Factor 2 is combustion (internal combustion engine emission and fossil fuel combustion) (30.5\%); Factor 3 is industrial $(8.1 \%)$; Factor 4 is diesel vehicle $(5.9 \%)$.

\section{CONCLUSIONS}

In this study, we observed the concentrations of the VOCs, as well as the gaseous pollutants $\mathrm{O}_{3}$ and $\mathrm{NO}_{x}$, online in Handan, one of the most polluted cities in China, from Sep. 2017 till Aug. 2018. Furthermore, we characterized the VOC pollution by determining the chemical reactivity of the VOCs, the individual VOCs' contributions to the $\mathrm{O}_{3}$ formation, and the associated source apportionment.

The annual VOC concentration in Handan was $112.0 \pm 45.5$ $\mu \mathrm{g} \mathrm{m}^{-3}$ on average, which exceeded the values reported for other Chinese cities (Beijing, Jinan, and Hefei) and foreign cities (Düzce and Calgary). The composition of the VOCs consisted of alkanes > aromatics > alkenes > alkynes, and

Table 2. Source apportionment of VOCs in four seasons.

\begin{tabular}{|c|c|c|c|c|c|c|}
\hline Source & PC1 & PC2 & PC3 & PC4 & PC5 & PC6 \\
\hline Spring & $\begin{array}{l}\text { LPG/NG and } \\
\text { solvent use }(27.0 \%)\end{array}$ & $\begin{array}{l}\text { Automobile exhaust } \\
(12.5 \%)\end{array}$ & $\begin{array}{l}\text { Diesel vehicle } \\
(11.8 \%)\end{array}$ & $\begin{array}{l}\text { Industrial } \\
(11.6 \%)\end{array}$ & $\begin{array}{l}\text { Solvent use } \\
(9.6 \%)\end{array}$ & \\
\hline Summer & $\begin{array}{l}\text { Gasoline } \\
\text { evaporation } \\
(20.7 \%)\end{array}$ & Solvent use (18.7\%) & $\begin{array}{l}\text { Automobile } \\
\text { exhaust }(14.5 \%)\end{array}$ & $\begin{array}{l}\text { Industrial } \\
(10.9 \%)\end{array}$ & $\begin{array}{l}\text { Diesel } \\
\text { vehicle } \\
(6.3 \%)\end{array}$ & $\begin{array}{l}\text { Biogenic } \\
(5.5 \%)\end{array}$ \\
\hline Autumn & $\begin{array}{l}\text { Solvent use and } \\
\text { fuel volatilization } \\
(36.7 \%)\end{array}$ & $\begin{array}{l}\text { Gasoline vehicle } \\
\text { emissions }(15.5 \%)\end{array}$ & Industrial $(8 \%)$ & $\begin{array}{l}\text { Diesel vehicle } \\
(6.6 \%)\end{array}$ & $\begin{array}{l}\text { Biomass } \\
\text { combustion } \\
(5.1 \%)\end{array}$ & \\
\hline Winter & $\begin{array}{l}\text { LPG/NG and } \\
\text { solvent use }(36.5 \%)\end{array}$ & $\begin{array}{l}\text { Combustion (internal } \\
\text { combustion engine } \\
\text { emission and fossil } \\
\text { fuel; } 30.5 \% \text { ) }\end{array}$ & $\begin{array}{l}\text { Industrial } \\
(8.1 \%)\end{array}$ & $\begin{array}{l}\text { Diesel vehicle } \\
(5.9 \%)\end{array}$ & & \\
\hline
\end{tabular}


the concentrations exhibited clear seasonality, following the order of winter $>$ autumn $>$ summer $>$ spring, with the values being 0.5 times higher during winter than spring.

A high incidence of $\mathrm{O}_{3}$ pollution was observed during summer, with the OFP of alkenes and other aromatics simultaneously increasing during medium pollution days. As the concentration of the $\mathrm{O}_{3}$ rose, the chemical reactivity of isoprene, $i$-pentane, and ethene notably climbed as well. The diurnal variation in the $\mathrm{VOC} / \mathrm{NO}_{x}$ ratio indicates that the $\mathrm{O}_{3}$ during spring and winter generally formed in VOCsensitive regimes, whereas high diurnal concentrations during summer and autumn, including an episode during which the 8-h concentration exceeded the Stage II limit specified by NAAQS, were generated in $\mathrm{NO}_{x}$-sensitive regimes.

The removal rate for ethylbenzene exceeded that of benzene: The ethylbenzene/acetylene ratio increased with the photochemical age, but the benzene/acetylene ratio displayed the opposite trend. The ambient ratios for $i$-butane $/ n$-butane and $i$-pentane $/ n$-pentane revealed that vehicular exhaust and liquid gasoline were the primary sources of butane and propane, respectively, during the observation period.

PCA identified the major VOC sources in Handan as industrial emissions, solvents, evaporated gasoline, and vehicular emissions. Their respective contributions varied slightly by season: High temperatures were conducive to gasoline and solvent evaporation during summer and autumn, and biogenic emissions were also more prominent during summer. During winter, however, the fraction from combustion increased significantly.

\section{ACKNOWLEDGMENTS}

This study was sponsored by the National Natural Science Foundation of China (Nos. 41475131, 41703088), National Key Program of Cause and Control of Severe Air Pollution (Nos. DQGG-05-09, DQGG-01-07, DQGG-02-09, DQGG03-04), Hebei Science Fund of Distinguished Young Scholars (No. D2017402086), Key Projects of Research and Development of Hebei Province (19273707D), the Program for the Outstanding Young Scholars of Hebei Province, the Hebei Support Program of Hundred Outstanding Innovative Talents from Universities (SLRC2017025), and Hebei Cultivating Project of Talent Development (A2016002022), National Natural Science Foundation (41703088).

\section{DISCLAIMER}

The authors declared that there are no conflict interest of reference to any companies or specific commercial products.

\section{SUPPLEMENTARY MATERIAL}

Supplementary data associated with this article can be found in the online version at https://doi.org/10.4209/aaqr.2 019.11.0608

\section{REFERENCES}

An, J., Zhu, B., Wang, H., Li, Y., Lin, X. and Yang, H.
(2014). Characteristics and source apportionment of VOCs measured in an industrial area of Nanjing, Yangtze River Delta, China. Atmos. Environ. 97: 206-214. https://doi.org/10.1016/j.atmosenv.2014.08.021

Atkinson, R. and Arey, J. (2003). Atmospheric degradation of volatile organic compounds. Chem. Rev. 103: 46054638. https://doi.org/10.1021/cr0206420

Bari, M.A. and Kindzierski, W.B. (2018). Ambient volatile organic compounds (VOCs) in Calgary, Alberta: Sources and screening health risk assessment. Sci. Total Environ. 631-632: 627-640. https://doi.org/10.1016/j.scitotenv.20 18.03.023

Barletta, B., Simone, M., Simpson, I.J., Khwaja, H.A., Donald, B. and Rowland, F.S. (2002). Mixing ratios of volatile organic compounds (VOCs) in the atmosphere of Karachi, Pakistan. Atmos. Environ. 36: 3429-3443. https://doi.org/10.1016/S1352-2310(02)00302-3

Baudic, A., Gros1, V., Sauvage, S., Locoge, N., Sanchez, O., Sarda-Estève, R., Kalogridis, Petit,J.E., Bonnaire, N., Baisnée, D., Favez, O., Albinet, A., Sciare, J. and Bonsang, B. (2016). Seasonal variability and source apportionment of volatile organic compounds (VOCs) in the Paris megacity (France). Atmos. Chem. Phys. 16: 11961-11989. https://doi.org/10.5194/acp-16-11961-2016

Bozkurt, Z., Üzmez, Ö.Ö., Döğeroğlu, T., Artun, G. and Gaga, E.O. (2018). Atmospheric concentrations of $\mathrm{SO}_{2}$, $\mathrm{NO}_{2}$, ozone and VOCs in Düzce, Turkey using passive air samplers: Sources, spatial and seasonal variations and health risk estimation. Atmos. Pollut. Res. 9: 1146-1156. https://doi.org/10.1016/j.apr.2018.05.001

Buzcu, B. and Fraser, M.P. (2006). Source identification and apportionment of volatile organic compounds in Houston, TX. Atmos. Environ. 40: 2385-2400. https://doi.org/10.1 016/j.atmosenv.2005.12.020

Carter, W.P.L. (1994). Development of ozone reactivity scales for volatile organic compounds. J. Air Waste Manage. Assoc. 44: 881-899. https://doi.org/10.1080/107 3161X.1994.10467290

Chang, C.C., Wang, J.L., Lung, S.C.C., Liu, S.C. and Shiu, C.J. (2009). Source characterization of ozone precursors by complementary approaches of vehicular indicator and principal component analysis. Atmos. Environ. 43: 17711778. https://doi.org/10.1016/j.atmosenv.2008.12.023

Chang, Q., Luo, Y., Jiang, J. and Ren, A. (2015). Pollution characteristic of VOCs of ambient air in winter and spring in Shijiazhuang city. J. Hebei Univ. Sci. Technol. 36: 330-336. https://doi.org/10.7535/hbkd.2015yx03017

Chen, X., Situ, S., Zhang, Q., Wang, X., Sha, C., Zhouc, L., Wu, L., Wu, L., Ye, L. and Li, C. (2019). The synergetic control of $\mathrm{NO}_{2}$ and $\mathrm{O}_{3}$ concentrations in a manufacturing city of southern China. Atmos. Environ. 201: 402-416. https://doi.org/10.1016/j.atmosenv.2018.12.021

de Gouw, J.A., Middlebrook, A.M., Warneke, C., Goldan, P.D., Kuster, W.C., Roberts, J.M., Fehsenfeld, F.C., Worsnop, D.R., Canagaratna, M.R., Pszenny, A.A.P., Keene, W.C., Marchewka, M.L., Bertman, S.B. and Bates, T.S. (2005). Budget of organic carbon in a polluted atmosphere: Results from the New England Air Quality Study in 2002. J. Geophys. Res. 110: D16305. 
http://doi.wiley.com/10.1029/2004JD005623

Franco, J.F., Pacheco, J., Behrentz, E. and Belalcázar, L.C. (2015). Characterization and source identification of VOC species in Bogotá, Colombia. Atmósfera 28: 1-11. https://doi.org/10.1016/S0187-6236(15)72155-7

Gao, W., Tie, X., Xu, J., Huang, R., Mao, X., Zhou, G. and Chang, L. (2017). Long-term trend of $\mathrm{O}_{3}$ in a mega city (Shanghai), China: Characteristics, causes, and interactions with precursors. Sci. Total Environ. 603-604: 425-433. https://doi.org/10.1016/j.scitotenv.2017.06.099

Gong, Y., Wei, Y., Cheng, J., Jiang, T., Chen, L. and Xu, B. (2017). Health risk assessment and personal exposure to Volatile Organic Compounds (VOCs) in metro carriagesA case study in Shanghai, China. Sci. Total Environ. 574: 1432-1438. https://doi.org/10.1016/j.scitotenv.2016.08.072

Hu, R., Liu, G., Zhang, H., Xue, H. and Wang, X. (2018). Levels, characteristics and health risk assessment of VOCs in different functional zones of Hefei. Ecotoxicol. Environ. Saf. 160: 301-307. https://doi.org/10.1016/j.eco env.2018.05.056

Huang, Z., Kong, S., Xing, X., Yao, M. and Qi, S. (2018). Monitoring of volatile organic compounds (VOCs) from an oil and gas station in northwest China for 1 year. Atmos. Chem. Phys. 18: 1-57. https://doi.org/10.5194/ac p-18-4567-2018

Hui, L., Liu, X., Tan, Q., Feng, M., An, J., Qu, Y., Zhang, Y. and Cheng, N. (2019). VOC characteristics, sources and contributions to SOA formation during haze events in Wuhan, Central China. Sci. Total Environ. 650: 2624 2639. https://doi.org/10.1016/j.scitotenv.2018.10.029

Kasparoglu, S., Incecik, S. and Topcu, S. (2018). Spatial and temporal variation of $\mathrm{O}_{3}, \mathrm{NO}$ and $\mathrm{NO}_{2}$ concentrations at rural and urban sites in Marmara Region of Turkey. Atmos. Pollut. Res. 9: 1009-1020. https://doi.org/10.1016 /j.apr.2018.03.005

Kumar, A., Singh, D., Kumar, K., Singh, B.B. and Jain, V.K. (2017). Distribution of VOCs in urban and rural atmospheres of subtropical India: Temporal variation, source attribution, ratios, OFP and risk assessment. Sci. Total Environ. 613-614: 492. https://doi.org/10.1016/j.s citotenv.2017.09.096

Lawrimore, J.H., Das, M. and Aneja, V.P. (1995). Vertical sampling and analysis of nonmethane hydrocarbons for ozone control in urban North Carolina. J. Geophys. Res. 100: 22785-22793. https://doi.org/10.1029/95JD02367

Leuchner, M., Gubo, S., Schunk, C., Wastl, C., Kirchner, M., Menzel, A. and Plass-Dülmer, C. (2015). Can positive matrix factorization help to understand patterns of organic trace gases at the continental Global Atmosphere Watch site Hohenpeissenberg? Atmos. Chem. Phys. 15: 1221-1236. https://doi.org/10.5194/acp-15-1221-2015

Li, B., Ho, S.S.H., Gong, S., Ni, J., Li, H., Han, L., Yang, Y., Qi, Y. and Zhao, D. (2019). Characterization of VOCs and their related atmospheric processes in a central Chinese city during severe ozone pollution periods. Atmos. Chem. Phys. 19: 617-638. https://doi.org/10.5194/acp-19-617-2019

Li, B., Ho, S.S.H., Xue, Y., Huang, Y., Wang, L., Cheng, Y., Dai, W., Zhong, H., Cao, J. and Lee, S. (2017). Characterizations of volatile organic compounds (VOCs) from vehicular emissions at roadside environment: The first comprehensive study in Northwestern China. Atmos. Environ. 161: 1-12. https://doi.org/10.1016/j.atmosenv.2 017.04.029

Li, Y., Lau, A.K.H., Fung, J.C.H., Zheng, J. and Liu, S. (2013). Importance of $\mathrm{NO}_{\mathrm{x}}$ control for peak ozone reduction in the Pearl River Delta region. J. Geophys. Res. 118: 9428-9443. https://doi.org/10.1002/jgrd.50659

Ling, Z.H., Guo, H., Cheng, H.R. and Yu, Y.F. (2011). Sources of ambient volatile organic compounds and their contributions to photochemical ozone formation at a site in the Pearl River Delta, southern China. Environ. Pollut. 159: 2310-2319. https://doi.org/10.1016/j.envpol.2011.0 5.001

Liu, B., Liang, D., Yang, J., Dai, Q., Bi, X., Feng, Y., Yuan, J., Xiao, Z., Zhang, Y. and Xu, H. (2016). Characterization and source apportionment of volatile organic compounds based on 1-year of observational data in Tianjin, China. Environ. Pollut. 218: 757-769. https://doi.org/10.1016/j.envpol.2016.07.072

Liu, Y., Shao, M., Fu, L., Lu, S., Zeng, L. and Tang, D. (2008). Source profiles of volatile organic compounds (VOCs) measured in China: Part I. Atmos. Environ. 42: 62476260. https://doi.org/10.1016/j.atmosenv.2008.01.070

Liu, Z., Li, N., Hou, L. and Lyu, B. (2014). Pollution characteristics and source identification of VOCs in ambient air of Jinan. Environ. Monit. China 30: 83-88. (in Chinese with English Abstract)

Lyu, X.P., Chen, N., Guo, H., Zhang, W.H., Wang, N., Wang, Y. and Liu, M. (2015). Ambient volatile organic compounds and their effect on ozone production in Wuhan, central China. Sci. Total Environ. 541: 200-209. https://doi.org/10.1016/j.scitotenv.2015.09.093

Ma, S., Wang, L., Wei, Z., Zhang, F., Meng, C. and Yang, J. (2016). Characterization of $\mathrm{PM}_{2.5}$ and it's chemical compositions under different air quality grades in Handan, China. Fresenius Environ. Bull. 25: 5162-5171.

McCarthy, M.C., Aklilu, Y.A., Brown, S.G. and Lyder, D.A. (2013). Source apportionment of volatile organic compounds measured in Edmonton, Alberta. Atmos. Environ. 81: 504-516. https://doi.org/10.1016/j.atmosen v.2013.09.016

Meng, C.C., Wang, L.T., Zhang, F.F., Wei, Z., Ma, S.M., Ma, X. and Yang, J. (2016). Characteristics of concentrations and water-soluble inorganic ions in $\mathrm{PM}_{2.5}$ in Handan city, Hebei Province, China. Atmos. Res. 171: 133-146. https://doi.org/10.1016/j.atmosres.2015.12.013

Nelson, P.F. and Quigley, S.M. (1983). The m, p-xylenes: Ethylbenzene ratio. A technique to estimating hydrocarbon age in ambient atmospheres. Atmos. Environ. 17: 659662. https://doi.org/10.1016/0004-6981(83)90141-5

Roberts, J.M., Fehsenfeld, F.C., Liu, S.C., Bollinger, M.J., Hahn, C., Albritton, D.L. and Sievers, R.E. (1984). Measurements of aromatic hydrocarbon ratios and $\mathrm{NO}_{\mathrm{x}}$ concentrations in the rural troposphere: Observation of air mass photochemical aging and $\mathrm{NO}_{\mathrm{x}}$ removal. Atmos. Environ. 18: 2421-2432. https://doi.org/10.1016/00046981(84)90012-X

Russo, R.S., Zhou, Y., White, M.L., Mao, H., Talbot, R. and 
Sive, B.C. (2010). Multi-year (2004-2008) record of nonmethane hydrocarbons and halocarbons in New England: seasonal variations and regional sources. Atmos. Chem. Phys.10: 1083-1134. https://doi.org/10.5194/acp10-4909-2010

Shao, P., An, J., Xin, J., Wu, F., Wang, J., Ji, D. and Wang, Y. (2016). Source apportionment of VOCs and the contribution to photochemical ozone formation during summer in the typical industrial area in the Yangtze River Delta, China. Atmos. Enviro. 176-177: 64-74. https://doi.org/10.1016/j.atmosres.2016.02.015

Sinha, V., Williams, J., Diesch, J.M., Drewnick, F., Martinez, M., Harder, H., Regelin, E., Kubistin, D., Bozem, H., Hosaynali-Beygi, Z., Fischer, H., AndrésHernández, M.D., Kartal, D., Adame, J.A. and Lelieveld, J. (2012). Constraints on instantaneous ozone production rates and regimes during DOMINO derived using in-situ $\mathrm{OH}$ reactivity measurements. Atmos. Chem. Phys. 12: 7269-7283. https://doi.org/10.5194/acp-12-7269-2012

Tan, J.H., Guo, S.J., Ma, Y.L., Yang, F.M., He, K.B., Yu, Y.C., Wang, J.W., Shi, Z.B. and Chen, G.C. (2012). Nonmethane hydrocarbons and their ozone formation potentials in Foshan, China. Aerosol Air Qual. Res. 12: 387-398. https://doi.org/10.4209/aaqr.2011.08.0127

Tan, Z., Lu, K., Jiang, M., Su, R., Dong, H., Zeng, L., Xie, S., Tan, Q. and Zhang, Y. (2018). Exploring ozone pollution in Chengdu, southwestern China: A case study from radical chemistry to $\mathrm{O}_{3}-\mathrm{VOC}-\mathrm{NO}_{\mathrm{x}}$ sensitivity. $\mathrm{Sci}$ Total Environ. 636: 775-786. https://doi.org/10.1016/j.sc itotenv.2018.04.286

Tang, X., Zhang, Y. and Sao, M. (2006). Atmospheric environmental chemistry. Higher Education Press.

U.S. EPA (1990). Health Effects Notebook for Hazardous Air Pollutants. https://www.epa.gov/haps/health-effectsnotebook-hazardous-air-pollutants

Wang, G., Cheng, S., Wei, W., Zhou, Y., Yao, S. and Zhang, H. (2016). Characteristics and source apportionment of VOCs in the suburban area of Beijing, China. Atmos. Pollut. Res. 7: 711-724. https://doi.org/10.1016/j.apr.20 16.03.006

Wang, H., Jing, S., Lou, S., Hu, Q., Li, L., Tao, S., Huang, C., Qiao, L. and Chen, C. (2017). Volatile organic compounds (VOCs) source profiles of on-road vehicle emissions in China. Sci. Total Environ. 607-608: 253261. https://doi.org/10.1016/j.scitotenv.2017.07.001

Wei, W., Lv, Z., Yang, G., Cheng, S., Li, Y. and Wang, L. (2016). VOCs emission rate estimate for complicated industrial area source using an inverse-dispersion calculation method: A case study on a petroleum refinery in Northern China. Environ Pollut. 218: 681-688. https://doi.org/10.1016/j.envpol.2016.07.062

Wei, W., Lv, Z.F., Li, Y., Wang, L.T., Cheng, S. and Liu, H. (2018). A WRF-Chem model study of the impact of VOCs emission of a huge petro-chemical industrial zone on the summertime ozone in Beijing, China. Atmos. Environ. 175: 44-53. https://doi.org/10.1016/j.atmosenv. 2017.11.058
Wei, Z., Wang, L., Ma, S., Zhang, F. and Yang, J. (2015). Source contributions of $\mathrm{PM}_{2.5}$ in the severe haze episode in Hebei Cities. Sci. World J. 2015: 1-11. https://doi.org/ $10.1155 / 2015 / 480542$

Xu, Z., Huang, X., Nie, W., Chi, X., Xu, Z., Zheng, L., Sun, P. and Ding, A. (2017). Influence of synoptic condition and holiday effects on VOCs and ozone production in the Yangtze River Delta Region, China. Atmos. Environ. 168: 112-124. https://doi.org/10.1016/j.atmosenv.2017.08.035

Yurdakul, S., Civan, M., Kuntasal, Ö., Doğan, G., Pekey, H. and Tuncel, G. (2018). Temporal variations of VOC concentrations in bursa atmosphere. Atmos. Pollut. Res. 9: 189-206. https://doi.org/10.1016/j.apr.2017.09.004

Zhang, C., Litao Wang, L., Qi, M., Ma, X., Zhao, L., Ji, S., Wang, Y., Lu, X., Wang, Q., Xu, R. and Ma, Y. (2018). Evolution of key chemical components in $\mathrm{PM}_{2.5}$ and potential formation mechanisms of serious haze events in Handan, China. Aerosol Air Qual. Res. 18: 1545-1557. https://doi.org/10.4209/aaqr.2017.10.0386

Zhang, Y., Wang, X., Barletta, B., Simpson, I.J., Blake, D.R., Fu, X., Zhang, Z., He, Q., Liu, T., Zhao, X. and Ding, X. (2013). Source attributions of hazardous aromatic hydrocarbons in urban, suburban and rural areas in the Pearl River Delta (PRD) region. J. Hazard. Mater. 250-251: 403-411. https://doi.org/10.1016/j.jhazmat.20 13.02.023

Zhao, L., Wang, L., Tan, J., Duanc, J., Ma, X., Zhang, C., Ji, S., Qi, M., Lu, X.H., Wang, Y., Wang, Q. and Xua, R. (2019). Changes of chemical composition and source apportionment of $\mathrm{PM}_{2.5}$ during 2013-2017 in urban Handan, China. Atmos. Environ. 226: 119-131. https://doi.org/10.1016/j.atmosenv.2019.02.034

Zhe, W., Wang, L., Hou, L., Zhang, H., Liang, Y., Wei, W., Ma, S., Zhang, C. and Xiao, M. (2019). Source apportionment of $\mathrm{PM}_{2.5}$ in Handan city, China using a combined method of receptor model and chemical transport model. Environ. Earth Sci. 11: 151-173. https://doi.org/10.1007/978-3-319-61630-8_13

Zheng, J., Yu, Y., Mo, Z., Zhang, Z., Wang, X., Yin, S., Peng, K., Yang, Y., Feng, X. and Cai, H. (2013). Industrial sector-based volatile organic compound (VOC) source profiles measured in manufacturing facilities in the Pearl River Delta, China. Sci. Total Environ. 456457: 127-136. https://doi.org/10.1016/j.scitotenv.2013.0 3.055

Zou, Y., Deng, X.J., Zhu, D., Gong, D.C., Wang, H., Li, F., Tan, H.B., Deng, T., Mai, B.R., Liu, X.T. and Wang, B.G. (2015). Characteristics of 1 Year of observational data of VOCs, $\mathrm{NO}_{\mathrm{x}}$ and $\mathrm{O}_{3}$ at a suburban site in Guangzhou, China. Atmos. Chem. Phys. 15: 6625-6636. https://doi.org/ 10.5194/acp-15-6625-2015

Received for review, December 19, 2019 Revised, March 26, 2020 Accepted, April 11, 2020 